\title{
The Potential of Locally-Sourced European Protein Sources for Organic Monogastric Production: A Review of Forage Crop Extracts, Seaweed, Starfish, Mussel, and Insects
}

\author{
Marleen Elise van der Heide ${ }^{1,2, *}$, Lene Stødkilde ${ }^{1,2}$, Jan Værum Nørgaard ${ }^{1}$ (D) and Merete Studnitz ${ }^{3}$ \\ 1 Department of Animal Science, Aarhus University, DK-8830 Tjele, Denmark; lsj@anis.au.dk (L.S.); \\ janvnoergaard@anis.au.dk (J.V.N.) \\ 2 Centre for Circular Bioeconomy, Aarhus University, DK-8830 Tjele, Denmark \\ 3 International Centre for Research in Organic Food Systems, DK-8830 Tjele, Denmark; \\ merete.studnitz@icrofs.org \\ * Correspondence: marleen.vanderheide@anis.au.dk.com
}

\section{check for}

updates

Citation: van der Heide, M.E.; Stødkilde, L.; Værum Nørgaard, J.; Studnitz, M. The Potential of Locally-Sourced European Protein Sources for Organic Monogastric Production: A Review of Forage Crop Extracts, Seaweed, Starfish, Mussel, and Insects. Sustainability 2021, 13, 2303. https://doi.org/10.3390/ su13042303

Academic Editor: Domenico Ronga

Received: 18 January 2021

Accepted: 16 February 2021

Published: 20 February 2021

Publisher's Note: MDPI stays neutral with regard to jurisdictional claims in published maps and institutional affiliations.

Copyright: (c) 2021 by the authors. Licensee MDPI, Basel, Switzerland. This article is an open access article distributed under the terms and conditions of the Creative Commons Attribution (CC BY) license (https:// creativecommons.org/licenses/by/ $4.0 /)$.

\begin{abstract}
Organic monogastric agriculture is challenged because of a limited availability of regional and organic protein-rich ingredients to fulfill the amino acid requirements. The development of novel feed ingredients is therefore essential. The use of starfish (Asterias rubens), mussel (Mytilus edilus), insect, green and brown seaweed, and forage crop extracts exhibits different approaches to increase protein availability in a sustainable manner through improving the protein quality of existing ingredients, better use of under- or unutilized material, or development of circular bioeconomy. This review assessed limitations and opportunities of producing, processing, and using these novel ingredients in feed. The use of non-renewable resources and the effect on the environment of production and processing the feed ingredients are described. Protein concentration and amino acid quality of the feed ingredients are evaluated to understand their substitution potential compared with protein-rich soya bean and fishmeal. Feedstuffs' effect on digestibility and animal performance is summarized. With the exception of seaweed, all novel ingredients show potential to partly substitute fishmeal or soya bean fulfilling part of the protein requirement in organic monogastric production. However, improvements during production and processing can be made to enhance protein quality, sustainability of the novel ingredients, and nutrient utilization of novel feed ingredients.
\end{abstract}

Keywords: novel feed ingredient; sustainability; pig; poultry; protein; amino acid; digestibility; growth performance

\section{Introduction}

In the European Union, at least $30 \%$ of protein feed for organic monogastrics must be made up of regionally-grown ingredients. Moreover, after 2025, all of the feed for organically produced monogastrics has to come from organic feed sources of agricultural origin within a year of feeding [1]. A limited availability of high quality and regionally produced protein sources certified for organic monogastric production hinders the sufficient supply of organic protein and thus amino acids (AA) to monogastrics' diets. In organic animal husbandry, the protein quality of feed ingredients is of particular importance since animal requirements for essential AA (EAA) have to be fulfilled without the addition of crystalline AA [2]. The use and development of alternative feed ingredients is therefore essential.

Alternative feed ingredients are typically evaluated in terms of their potential to substitute the conventional ingredients, fishmeal, or soya bean. This is due to their high protein level and the good AA profile, i.e., fitting animal's requirements. Nonetheless, it is desirable to lower the dependency on soya and fishmeal as both of these conventional feed ingredients can have negative effects on environmental and economic sustainability. Soybean meal causes deforestation and emissions from long transport distances [3]. 
Although organic deforestation-free soya can be used, Northern European countries, in particular, still depend on imports because production within Europe largely takes place in Eastern and Southern Europe [4]. Overfishing negatively affects ecosystem resilience [5]. Variation in availability due to, e.g., overfishing [6] or limited agricultural land areal as well as competition for these ingredients leads to high and volatile prices. Competition for these resources may increase further with the predicted increase in human population growth since this is expected to enhance demand for protein-rich agricultural commodities [7]. Therefore, protein sources that do not compete with human food are desirable.

Blue mussel (Mytilus edilus), starfish (Asterias rubens), seaweed, protein extracted from forage crops (green protein) and insects can all be produced in Northern Europe. Moreover, all of these ingredients can play a role in circular and sustainable feed production. Although red seaweeds contain a high protein fraction, the focus in this review will be on three seaweeds that are common and abundant in Northern Europe and have been of interest for animal feed: Ascophylum nodosum, Saccharina latissima and Ulva lactuca. In terms of insects, focus will be on the black soldier fly (Hermetia illucens), the yellow mealworm (Tenebrio molitor), and the lesser mealworm (Alphitobius diaperinus). Production of these insects is already established and there is potential for them to be produced at large scale [8]. However, processed insects are not yet allowed in monogastrics' feed under EU regulation. Living insects are allowed in poultry nutrition. Protein extracts from perennial ryegrass (Lolium perenne), lucerne (Medicago sativa L.), and red clover (Trifolium pretense L.) are included in the review as these forage crops are commonly grown in Northern Europe either as monocultures or as constituents of forage mixtures.

In this review, the potential of using cultivated blue mussel, starfish, seaweed, protein extracted from forage crops (green protein), and insects as alternative feed ingredients in European organic monogastric nutrition will be evaluated on the basis of their potential sustainability, nutrient composition, and their effect on animal performance.

\section{Sustainability}

\subsection{Sustainability during Production}

EU rules for organic production promote sustainable agriculture and encompass the efficient and restricted use of external inputs and non-renewable resources ([1]; articles 5 and 6). The growth or cultivation of aquatic ingredients, i.e., seaweed, starfish, and mussel, requires no arable land because they grow in water. Although wild harvest is the main harvesting method of seaweeds in Europe [9], interest in seaweed cultivation is increasing $[10,11]$. Starfish are a by-product of mussel cultivation in which overabundant starfish are caught to prevent losses in mussel populations due to predation. The rearing of insects does require a low amount of non-agricultural land, moreover, insect feed can be associated with the use of arable land and water. When cultivating perennial forage crops from which protein can be extracted, arable land is used in a more sustainable way compared with annual crops such as seed crops. Perennial crops cover the soil all year round and have longer growing seasons [12,13]. Moreover, their extensive root systems increase competitiveness against weeds and biomass yields [12,13].

Growing aquatic ingredients does not require any non-renewable resources, such as $\mathrm{N}$, P, or water, during growth because they utilize nutrients that naturally occur in the water. Mussels effectively remove $0.60-1.27 \mathrm{t} \mathrm{N} \mathrm{ha}^{-1}$ and $0.04-0.10 \mathrm{t} \mathrm{P} \mathrm{ha}{ }^{-1}$ from the water [14]. The removal of these nutrients from the water promotes circular production by mitigating eutrophication in areas with a excess nutrients [15]. Similarly, the removal of starfish and seaweed will give a net removal of nutrients from the water, although to a lesser extent than mussels. Seaweeds are less efficient biofilters than mussels [16]. Conversely, insects and forage crops need external input of non-renewable resources for growth. For forage crops, the nutrient input depends on the cultivation method. Forage crops are effective at capturing nutrients and water and consequently minimize nutrient leaching [17] and increase soil $\mathrm{N}$ supply in crop rotations [18,19]. For insects, the input of resources depends on the utilized feeding substrate and insects' feed efficiency. Insects 
can be highly efficient in turning low-quality biomass into high-quality protein, but this largely depends on diet composition as well as insect species [20,21]. The high efficiency is related to the fact that insects are poikilothermic, i.e., they do not use energy for regulation of body temperature. This enables them to utilize ingested energy for metabolic processes instead of thermoregulation. The diet for insects should consist of previously unutilized biomass such as waste and low-value side streams, and not traditional livestock feedstuffs, to be truly sustainable. However, currently, there are limitations for the feed allowed in insect rearing. Since insects are considered livestock, the ingredients allowed in insects' diets are subjected to EU regulation [22], which lays down restrictions on the use of among others catering waste and processed animal protein. Moreover, in the future additional restrictions may apply for organically reared insects under EU legislation.

Knowledge on energy use and potential greenhouse gas (GHG) emissions is relevant in organic agriculture to comply with responsible use of energy and low-carbon economy ([1]; article 5). Anthropogenic GHG emissions and utilization of external energy are non-existent during the growing period of the aquatic ingredients. In fact, seaweeds may be a sink for carbon sequestration [23]. Similarly, some perennial forage crops and legumes can sequestrate carbon in soils. Moreover, legumes contribute to reduced GHG emissions because of decreased GHG release and reduced fossil energy input [24]. Energy is, however, required to regulate temperature during the production of poikilothermic insects. Oonincx and De Boer [25] found that $43 \%$ of energy used during insect production was due to the use of heat and electricity. Furthermore, GHG release may be associated with metabolic processes and microbial respiration during insect production [26]. Parodi et al. [26] observed that carbon was mainly emitted as $\mathrm{CO}_{2}$. The GHG emissions may also be associated with the feed used for insect rearing. In order to fully understand the environmental sustainability of insects as an alternative to soya bean, the global warming potential of insects compared to soya bean should be established. Besides emissions directly linked to the production process, $\mathrm{CO}_{2}$ emissions are often related to transport. Therefore, EU organic regulation stimulates short distribution channels and local production ([1]; article 4). Mussel, seaweed, and starfish species discussed in this review all occur in Northern Europe, hence in many coastal areas they could fulfil part of the requirements for locally-sourced feed in organic monogastric production. Regional production is also possible for insects, which are not bound to land, and forage crops.

EU regulation requires stimulation of biodiversity and no harm to the environment ([1]; articles 4 and 5). Relative to annual crops, cultivation of perennial crops has substantial ecological and economic benefits because of reduced soil erosion and a provision of a continuous habitat for wildlife [17]. The quantity and harvest method of seaweeds, starfish and mussel may affect the surrounding fauna as well as population dynamics and should therefore be taken into account when determining the method and quantity to be harvested. In this regard, the harvest of starfish did not destroy the underlying sea bed when using a purse seine [27]. Moreover, this method had low by-catch and did not affect biodiversity of infauna or abundance of species in the Danish Limfjord. The impact of mussel cultivation depends on the cultivation method. Dredging of the bottom when mussels are grown on natural beds ruins the seabed, and therefore methods using line or net cultivation are more sustainable [28]. Furthermore, mussels have been found to improve water transparency and reduce chlorophyll $a$, which is related to the presence of plankton, bacteria, larvae, fish eggs, and other small biological organisms, in a large area surrounding a mussel cultivation site [29]. Furthermore, even though excretion of nutrients by mussels will increase local sedimentation of nutrients, nutrient loading is reduced when taking into account an entire water body due to net removal of nutrients [29].

The harvested quantity of different ingredients affects their availability for feed. A consequence of extensive production of aquatic products is fluctuation in quantity depending on biological factors. Low quantities, i.e., quantities that do not sustain profitability of harvest and processing, can be a bottleneck for the continuous production of aquatic ingredients for feed. In contrast, perennial crops for green protein and insects are grown 
with the help of human interventions, hence quantities are less variable. Insect production can be scaled under controlled circumstances according to demand and feed substrate availability. The quantity of perennial crops is affected by available arable land mass, which can also be used for monocultures of annual crops, which are sown on more than two-thirds of global cropland for animal feed production, human consumption, and non-food goods (e.g., biofuel) [12,17].

Availability for feed is also dependent on the competition for these ingredients as food as well as non-food goods. Competition for forage crops can be large because of its multiple purposes. Traditionally, forage crops are used for animal production, mostly for ruminants; however, recently the crops have been considered for production of monogastric feed protein as well as for non-nutrition purposes such as production chemicals and materials [30,31]. Insects are mainly of interest for their nutritious quality as a feed or food. However, the use of insects for food is limited by consumer perception of insects as food [32]. In contrast, starfish and mussels intended for feed do not compete with food. This is because mussels intended for feed are either waste mussels, i.e., undersized mussels [33], or mussels farmed to mitigate water eutrophication, which are generally less suited for human consumption because of uneven and small sizes [29]. Besides quantity, also quality of the products should be taken into account as this determines how efficiently feed ingredients can be converted into animal protein. This will be reviewed in upcoming sections.

\subsection{Sustainability at Processing}

The processing of the ingredients studied in this review requires low input of external processing aids and can be done using mechanical and physical processes. Responsible use of energy should be taken into account for the organic processing of feed ingredients. Heat, and thus energy is required for drying and grinding, which is essential to prevent microbial spoilage and to elongate shelf life [34,35]. The dry matter (DM) of seaweed can be as low as $14 \%$ and thus requires a significant effort to dry [36]. Energy used for processing of seaweeds is for up to $60 \%$ taken up by drying [37].

High input of energy, as well as water, is also required when processing mussels because they are generally boiled to remove the shell and to obtain the protein-rich meat fraction. It is difficult to develop alternative processing methods that provide a meal of equally high quality. Alternative methods will often have parts of the shell remaining in the meal fraction. This means that the contribution of protein will be lower, whereas the contribution of ash will be higher, because mussel shell is made up of around $94 \%$ ash in DM [38].

Pre-processing can also be done for insects. The black soldier fly is often defatted mechanically, as this insect can have a fat content of close to $40 \%[39,40]$. A benefit of defatting is the generation of a product with a higher protein concentration.

The improvement of product quality is also the main merit of protein extraction from forage crops. The efficient use of green biomass (annual and perennial) as a source of monogastric feed protein requires separation of the protein from the plant fiber matrix. Numerous different separation techniques have been applied; however, several recent studies have applied screw-press processing to achieve a protein-rich juice and a fibrous pulp [41-45]. Soluble proteins in the plant juice can be extracted via different methods where heat treatment, acidification, or fermentation are commonly used methods [46]. The result is a protein extract or concentrate commonly referred to as green protein and a residual brown juice [44]. Efficient utilization of the produced fractions is a major contributor to the sustainability of the biorefining concept [47]. Production of a protein concentrate for monogastrics as a sole product will limit the competitiveness of the production, and the biorefining concept must include efficient use of the pulp fraction [41,48]. The pulp fraction may be used as feed for ruminants [49], for biogas [50] or bioethanol production [35]. The methods applied all require fresh biomass due to the need for intact protein for precipitation [43]. This requirement introduces seasonal challenges with biomass supply and 
hence limits the running hours on the biorefinery. Using ensiled forage crops as input for the biorefinery and a subsequent feeding with the plant juice is tested as alternative approaches [51], which would make production during the winter possible and would reduce the need for drying.

\section{Nutrient Composition of Alternative Ingredients}

In this section, an overview of the nutrient composition of meal from mussel, starfish, seaweed, insects, and forage crop protein extract will be given from data extracted from literature on either dried or fresh ingredients. Units of extracted data have been equalized, and average, standard deviation (SD), and coefficient of variation (CV) have been calculated. Nutrient levels, in particular crude protein (CP, Nx6.25) and EAA, in alternative feed ingredients will be compared to those in fishmeal or organic soya bean in order to determine their substitution potential based on nutritional value. The chemical composition of the aforementioned conventional ingredients is depicted in Table 1. Table 1 also contains average data for wheat (non-organic), which is more similar to seaweed in terms of CP concentration. Besides the nutrient concentration, also the variation in nutrient composition of the different feed ingredients among studies will shortly be discussed because harvesting and growing conditions affect nutrient composition of alternative feed ingredients. In the different tables, the coefficient of variation and SD are used to visualize the nutrient variability within feed ingredients among different studies.

Table 1. Chemical composition of macronutrients (g/100 g DM), minerals (g/kg DM) and amino acid (AA) profile (g/100 g $\mathrm{CP}$ ) in meal from commonly fed ingredients.

\begin{tabular}{|c|c|c|c|c|c|c|c|c|c|}
\hline \multirow{2}{*}{$\frac{\text { Item }}{\text { Macronutrient }}$} & \multicolumn{3}{|c|}{ Wheat ${ }^{1}$} & \multicolumn{3}{|c|}{ Fish Meal $^{2}$} & \multicolumn{3}{|c|}{ Organic Soya Bean ${ }^{3}$} \\
\hline & $\mathbf{N}$ & $\operatorname{Avg} \pm \mathrm{SD}^{4}$ & $\mathrm{CV}^{5}$ & $\mathbf{N}$ & $\operatorname{Avg} \pm \mathrm{SD}$ & $\mathrm{CV}$ & $\mathbf{N}$ & $\operatorname{Avg} \pm \mathrm{SD}$ & $\mathrm{CV}$ \\
\hline Crude ash & 6 & $1.83 \pm 0.18$ & 10.0 & 5 & $18.8 \pm 2.66$ & 14.2 & 3 & $6.41 \pm 0.44$ & 6.91 \\
\hline Crude fat & 7 & $2.15 \pm 0.42$ & 19.5 & 4 & $9.51 \pm 0.47$ & 4.97 & 3 & $14.5 \pm 6.86$ & 47.3 \\
\hline $\begin{array}{l}\text { Crude protein } \\
\text { Minerals }\end{array}$ & 8 & $14.2 \pm 2.00$ & 14.1 & 6 & $71.4 \pm 2.45$ & 3.43 & 5 & $44.6 \pm 3.65$ & 8.17 \\
\hline Calcium & 6 & $0.43 \pm 0.27$ & 62.4 & 4 & $41.4 \pm 8.52$ & 20.6 & 2 & $3.55 \pm 0.15$ & 4.23 \\
\hline $\begin{array}{c}\text { Phosphorus } \\
\qquad E A A^{6}\end{array}$ & 5 & $4.02 \pm 0.48$ & 12.0 & 4 & $30.4 \pm 6.15$ & 20.2 & 2 & $6.15 \pm 0.75$ & 12.2 \\
\hline Histidine & 4 & $2.58 \pm 0.24$ & 9.17 & 5 & $2.52 \pm 0.58$ & 23.1 & 5 & $2.65 \pm 0.08$ & 2.97 \\
\hline Isoleucine & 8 & $3.36 \pm 0.19$ & 5.53 & 5 & $4.00 \pm 0.11$ & 2.79 & 5 & $4.54 \pm 0.24$ & 5.36 \\
\hline Leucine & 4 & $6.47 \pm 0.17$ & 2.59 & 5 & $6.88 \pm 0.31$ & 4.57 & 5 & $7.60 \pm 0.18$ & 2.42 \\
\hline Lysine & 8 & $3.18 \pm 0.30$ & 9.56 & 5 & $7.47 \pm 0.37$ & 4.99 & 5 & $6.09 \pm 0.16$ & 2.69 \\
\hline Methionine & 8 & $1.53 \pm 0.08$ & 5.06 & 5 & $2.68 \pm 0.12$ & 4.63 & 5 & $1.40 \pm 0.06$ & 3.93 \\
\hline Phenylalanine & 4 & $4.30 \pm 0.23$ & 5.33 & 5 & $3.83 \pm 0.17$ & 4.51 & 5 & $4.95 \pm 0.19$ & 3.86 \\
\hline Threonine & 8 & $2.90 \pm 0.11$ & 3.76 & 5 & $4.01 \pm 0.23$ & 5.80 & 5 & $3.86 \pm 0.20$ & 5.10 \\
\hline Tryptophan & 5 & $1.17 \pm 0.05$ & 3.98 & 2 & $0.93 \pm 0.08$ & 8.78 & 4 & $1.36 \pm 0.18$ & 13.1 \\
\hline $\begin{array}{l}\text { Valine } \\
N E A A^{7}\end{array}$ & 5 & $4.32 \pm 0.26$ & 5.97 & 5 & $4.66 \pm 0.12$ & 2.67 & 5 & $4.84 \pm 0.24$ & 5.02 \\
\hline Alanine & 8 & $3.36 \pm 0.40$ & 11.8 & 5 & $6.17 \pm 0.10$ & 1.68 & 5 & $4.24 \pm 0.20$ & 4.72 \\
\hline Arginine & 5 & $4.97 \pm 0.40$ & 8.00 & 5 & $5.75 \pm 0.24$ & 4.20 & 5 & $7.38 \pm 0.32$ & 4.28 \\
\hline Aspartic acid & 4 & $5.37 \pm 0.38$ & 7.13 & 5 & $6.93 \pm 3.24$ & 46.7 & 5 & $11.3 \pm 0.55$ & 4.86 \\
\hline Cysteine & 4 & $2.20 \pm 0.16$ & 7.23 & 5 & $1.11 \pm 0.64$ & 57.8 & 5 & $1.54 \pm 0.12$ & 7.80 \\
\hline Glutamic acid & 4 & $26.9 \pm 2.22$ & 8.26 & 5 & $12.2 \pm 1.08$ & 8.83 & 5 & $18.0 \pm 0.48$ & 2.65 \\
\hline Glycine & 4 & $4.28 \pm 0.32$ & 7.48 & 5 & $6.99 \pm 0.60$ & 8.63 & 5 & $4.20 \pm 0.14$ & 3.45 \\
\hline Proline & 4 & $8.19 \pm 1.50$ & 18.4 & 5 & $4.91 \pm 0.64$ & 13.0 & 5 & $4.53 \pm 1.18$ & 26.0 \\
\hline Serine & 4 & $4.50 \pm 0.34$ & 7.49 & 5 & $4.04 \pm 0.85$ & 21.1 & 5 & $4.86 \pm 0.41$ & 8.39 \\
\hline Tyrosine & 2 & $2.97 \pm 0.12$ & 4.17 & 5 & $3.69 \pm 1.11$ & 30.1 & 4 & $3.39 \pm 0.13$ & 3.71 \\
\hline$\sum \mathrm{AA}$ & 4 & 90.6 & & 5 & 88.2 & & 5 & 95.7 & \\
\hline$\sum E A A$ & 4 & 29.1 & & 5 & 36.4 & & 5 & 37.0 & \\
\hline$\sum N E A A$ & 4 & 61.5 & & 5 & 51.8 & & 5 & 58.7 & \\
\hline EAA:NEAA & 4 & 0.47 & & 5 & 0.70 & & 5 & 0.63 & \\
\hline
\end{tabular}

${ }^{1}$ Based on literature values: [52-57]; ${ }^{2}$ Based on literature values [58-63]; ${ }^{3}$ Based on literature values: [64-67]; ${ }^{4}$ Average \pm standard deviation over included studies; ${ }^{5}$ Coefficient of variation over included studies; ${ }^{6}$ Essential amino acids; ${ }^{7}$ Non-essential amino acids. 


\subsection{Mussel Meal and Starfish Meal as Compared to Fishmeal}

Mussel meal (Mytilus edilus) and starfish meal (Asterias rubens; Table 2) are both animal protein and therefore a comparison with fishmeal will be made. Mussel meal contains a high level of $\mathrm{CP}$ at $66 \%$ in dry matter (DM), which is slightly below the $71 \% \mathrm{CP}$ in $\mathrm{DM}$ in fishmeal. Starfish meal, on the other hand, has a considerably lower CP content (39\% of $\mathrm{DM}$ ) than fishmeal. On the basis of $\mathrm{CP}$ concentration, mussel meal will contribute a similar amount of $\mathrm{CP}$ to the complete diets as fish meal, hence mussel meal could almost completely substitute fishmeal. Starfish meal, however, will contribute less $C P$, and conversely less AA to the complete feed. The ratio of EAA to non-essential (NEAA) is similar between fishmeal and mussel meal, whereas starfish meal has a lower ratio than either of these feed ingredients. This coincides with lower levels of most of the EAA (g/100 g CP) in starfish meal compared with fishmeal or mussel meal. The EAA profile is comparable for all three feed ingredients in that lysine and leucine are most abundant, and tryptophan and histidine are least abundant. A high content of EAA, particularly lysine and leucine, fits with pigs' high requirements for these AA [68]. The lower methionine concentration in starfish meal compared with mussel meal and fishmeal makes it a less suitable source of methionine. The high ash concentration in starfish meal (35-55\% DM) is the main limiting factor for its inclusion in complete diets because of a wide Ca:P ratio.

The fat content of mussel meal and starfish meal is more variable than that in fishmeal. Moreover, the protein content of starfish meal is highly variable in comparison with fishmeal and mussel meal. Changes in the environmental conditions of mussel and starfish will alter growth conditions and nutrient availability. Environmental factors, such as salinity, temperature, light intensity, food availability and oxygen saturation, vary depending on the season [33,69-71]. A main determining factor for nutrient variation of starfish and mussel is the reproductive cycle $[33,72]$ which alters energy and protein requirements. Seasonal variation on $\mathrm{CP}$, fat, and ash content of starfish was indeed related to the reproductive cycle in a study on annual variation of macronutrients of starfish from Danish waters in a one-year study [73]. On the basis of an inverse relation between $\mathrm{CP}$ and ash, an optimum harvesting time of starfish with low ash and high CP level could be determined. However, it is not known how annual and spatial differences affect the optimum harvesting time of starfish. Mussel meal has a less variable concentration of ash and protein than starfish meal. This might be related to the cultivation method; mussels, produced for environmental mitigation purposes, are grown under controlled conditions at established and fixed production sites. Starfish, on the other hand, are not produced under controlled conditions because they are harvested from the seabed. Therefore, nutrient composition within and between batches of starfish may be more variable although harvesting at the optimum time will likely minimize this variation.

Table 2. Chemical composition of macronutrients (g/100 g DM), minerals (g/kg DM), and amino acid (AA) profile (g/100 $\mathrm{g} \mathrm{CP}$ ) in meal from blue mussel meat (Mytilus edilus) and starfish meal (Asterias rubens).

\begin{tabular}{|c|c|c|c|c|c|c|}
\hline \multirow[t]{2}{*}{ Item } & \multicolumn{3}{|c|}{ Mussel Meal ${ }^{1}$} & \multicolumn{3}{|c|}{ Starfish Meal ${ }^{2}$} \\
\hline & $\mathbf{N}$ & $\operatorname{Avg} \pm \mathrm{SD}^{3}$ & $\mathrm{CV}^{4}$ & $\mathbf{N}$ & $\operatorname{Avg} \pm \mathrm{SD}$ & CV \\
\hline Crude ash & 5 & $8.61 \pm 0.91$ & 10.5 & 15 & $45.0 \pm 9.98$ & 22.2 \\
\hline Crude fat & 5 & $10.1 \pm 3.26$ & 32.2 & 15 & $8.28 \pm 1.40$ & 16.8 \\
\hline $\begin{array}{l}\text { Crude protein } \\
\text { Minerals }\end{array}$ & 5 & $66.4 \pm 3.86$ & 5.82 & 15 & $39.0 \pm 9.69$ & 24.8 \\
\hline Calcium & 2 & $7.00 \pm 2.00$ & 28.6 & 15 & $129 \pm 31.5$ & 24.5 \\
\hline $\begin{array}{c}\text { Phosphorus } \\
E A A^{5}\end{array}$ & 2 & $8.50 \pm 0.50$ & 5.88 & 15 & $6.31 \pm 5.64$ & 89.4 \\
\hline Histidine & 5 & $1.85 \pm 0.17$ & 9.32 & 15 & $1.65 \pm 0.11$ & 6.53 \\
\hline Isoleucine & 5 & $3.96 \pm 0.57$ & 14.3 & 15 & $3.61 \pm 0.12$ & 3.42 \\
\hline Leucine & 5 & $6.10 \pm 0.83$ & 13.7 & 15 & $5.36 \pm 0.35$ & 6.60 \\
\hline
\end{tabular}


Table 2. Cont.

\begin{tabular}{|c|c|c|c|c|c|c|}
\hline \multirow[t]{2}{*}{ Item } & \multicolumn{3}{|c|}{ Mussel Meal ${ }^{1}$} & \multicolumn{3}{|c|}{ Starfish Meal ${ }^{2}$} \\
\hline & $\mathbf{N}$ & $\operatorname{Avg} \pm \mathrm{SD}^{3}$ & $\mathrm{CV}^{4}$ & $\mathbf{N}$ & $\operatorname{Avg} \pm S D$ & $\mathrm{CV}$ \\
\hline Lysine & 5 & $6.78 \pm 0.69$ & 10.1 & 15 & $5.65 \pm 0.38$ & 6.78 \\
\hline Methionine & 4 & $2.37 \pm 0.40$ & 16.7 & 15 & $1.95 \pm 0.18$ & 9.15 \\
\hline Phenylalanine & 5 & $3.43 \pm 0.45$ & 13.2 & 15 & $3.22 \pm 0.15$ & 4.52 \\
\hline Threonine & 5 & $4.18 \pm 0.51$ & 12.3 & 15 & $4.40 \pm 0.53$ & 12.0 \\
\hline Tryptophan & 1 & 1.20 & & 14 & $0.98 \pm 0.10$ & 10.6 \\
\hline Valine & 5 & $3.97 \pm 0.51$ & 12.8 & 15 & $4.49 \pm 0.37$ & 8.27 \\
\hline \multicolumn{7}{|l|}{$N E A A^{6}$} \\
\hline Alanine & 5 & $4.57 \pm 0.41$ & 9.07 & 15 & $5.00 \pm 0.44$ & 8.73 \\
\hline Arginine & 5 & $6.49 \pm 0.77$ & 11.9 & 15 & $5.82 \pm 0.22$ & 3.82 \\
\hline Aspartic acid & 5 & $9.00 \pm 1.16$ & 12.9 & 15 & $8.43 \pm 0.15$ & 1.76 \\
\hline Cysteine & 4 & $1.51 \pm 0.50$ & 32.7 & 15 & $1.39 \pm 0.22$ & 15.7 \\
\hline Glutamic acid & 5 & $11.8 \pm 1.31$ & 11.1 & 15 & $10.0 \pm 2.39$ & 23.9 \\
\hline Glycine & 5 & $5.65 \pm 0.50$ & 8.78 & 15 & $14.2 \pm 1.97$ & 13.9 \\
\hline Proline & 5 & $3.52 \pm 0.42$ & 11.8 & 15 & $4.50 \pm 0.35$ & 7.75 \\
\hline Serine & 5 & $4.11 \pm 0.69$ & 16.8 & 15 & $5.08 \pm 1.13$ & 22.2 \\
\hline Tyrosine & 3 & $3.29 \pm 0.56$ & 17.1 & 1 & 2.94 & \\
\hline$\sum \mathrm{AA}$ & 5 & 80.8 & & 15 & 85.8 & \\
\hline$\sum E A A$ & 5 & 32.4 & & 15 & 31.2 & \\
\hline$\sum$ NEAA & 5 & 48.3 & & 15 & 54.6 & \\
\hline EAA:NEAA & 5 & 0.67 & & 15 & 0.58 & \\
\hline
\end{tabular}

${ }^{1}$ Based on literature values: [38,74-77]; ${ }^{2}$ Based on literature values: $[63,73,74,78] ;{ }^{3}$ Average \pm standard deviation over included studies; ${ }^{4}$ Coefficient of variation over included studies; ${ }^{5}$ Essential amino acids; ${ }^{6}$ Non-essential amino acids.

\subsection{Seaweed Meal as Compared to Soya Bean and Wheat}

Seaweeds' nutrient composition (Table 3) will be compared to soya bean and to wheat. Brown seaweeds have a low protein concentration of 7.6 and $10.7 \%$ CP in DM for S. latissima and $A$. nodosum, respectively. The green seaweed, $U$. lactuca, contains about twice as much protein, i.e., $19.0 \%$ CP in DM on average. Protein levels of seaweeds are clearly lower than what is found in soya bean (Table 1). Hence, seaweeds will supply little protein to complete diets for monogastric animal and thus, in their intact form, will not be a good substitute for protein-rich feed ingredients. In terms of protein level, they are more suitable as a substitute for wheat (Table 1). Despite the low CP level, on average A. nodosum and U. lactuca contain a similar, slightly lower, ratio of EAA:NEAA compared to soya bean. This ratio is clearly lower for S. latissima, which has a ratio comparable to wheat. Besides supplying less protein, the protein fraction in seaweeds also contains less lysine compared to that in soya bean. This means that more lysine has to come from another source in order to fulfil monogastrics' high requirements for lysine. Leucine is the most abundant AA in all seaweeds. With the exception of $A$. nodosum, leucine levels in seaweeds are comparable to that in soya bean. Histidine and methionine in $\mathrm{g} / 100 \mathrm{~g} \mathrm{CP}$ are low in all seaweeds. However, the relative methionine levels in seaweeds are similar to the levels in soya bean and wheat. The histidine levels of all seaweeds, on the other hand, are clearly lower than that in soya bean. Carbohydrates make up the majority of seaweeds, i.e., at least $50 \%$ of DM. The carbohydrate fraction is made up of mostly indigestible polysaccharides from the algae cell wall [79]. The nutritional value of these carbohydrates depends on their fermentation potential, which provides the animal with some energy from short chain fatty acids. A high inclusion of seaweed meal with indigestible fiber will lead to a dilution of digestible macronutrients in the diet. The high fiber fraction will, moreover, limit the availability of digestible nutrients. Polysaccharides may limit absorption of other nutrients. Firstly, non-digestible polysaccharides can trap protein in cellular matrix, thereby making protein inaccessible for digestive enzymes [80]. Acid detergent lignin is negatively correlated with in vitro protein digestibility of seaweeds [81]. Alginates, which are prevalent in brown seaweeds [82], can increase digesta viscosity and thereby limit the efficient distribution of enzymes [83]. Lastly, phenolic compounds in seaweeds may depress protein digestibility by precipitating dietary protein [84]. Seaweeds contain between $15 \%$ and $30 \%$ crude ash (Table 2). This is considerably higher than the ash level 
in soya bean. Similar to fiber, ash concentration of seaweed limits the inclusion level in feed. Firstly, a too high inclusion of seaweeds will dilute the feed ration thus allowing less space for required nutrients. Secondly, an excess in certain minerals may be toxic and reduce animal performance [68]. Moreover, excess minerals will end up in the environment because mineral concentrations in the body are tightly regulated [85]. Most macro-minerals in seaweeds are present at levels far above those in wheat or soya bean. Except for an excess in minerals, also imbalances among minerals may limit seaweeds' inclusion level in feed rations. The balance among $\mathrm{Na}, \mathrm{Cl}$, and $\mathrm{K}$ can affect the electrolyte balance in the animal, which affects optimum growth performance [86]. Moreover, low phosphorus, which is present at a lower concentration in seaweeds than in the conventional feed ingredients, will contribute to a wide and undesirable Ca:P ratio.

All nutrients within seaweed species are highly variable among studies. Seaweeds are grown in natural waters, and therefore location, season, and environmental factors, such as $\mathrm{pH}$, temperature, sunlight, and nutrient content of water, affect their nutrient composition $[36,87,88]$. Therefore, each harvested batch of seaweeds should be analyzed if they are to be used as feed ingredients. The seaweeds described in this review provide only a very low amount of protein; therefore, intact seaweed may not be a good protein source to fulfil the gap in available feed protein. The currently low production potential combined with a high energy input at drying makes it difficult to develop these seaweed into sustainable animal feed for organic monogastric animals. Therefore, intact brown and green seaweeds will not be further discussed in this review.

Table 3. Chemical composition of macronutrients (g/100 g DM), minerals (g/kg DM), and amino acid (AA) profile (g/100 g $\mathrm{CP}$ ) in green (U. lactuca) and brown seaweeds (A. nodosum and S. latissima).

\begin{tabular}{|c|c|c|c|c|c|c|c|c|c|}
\hline \multirow[t]{2}{*}{ Item } & \multicolumn{3}{|c|}{ Ulva lactuca ${ }^{1}$} & \multicolumn{3}{|c|}{ Ascophyllum nodosum ${ }^{2}$} & \multicolumn{3}{|c|}{ Saccharina latissimi ${ }^{3}$} \\
\hline & $\mathbf{N}$ & $\operatorname{Avg} \pm \mathrm{SD}^{4}$ & $\mathrm{CV}^{5}$ & $\mathbf{N}$ & $\operatorname{Avg} \pm \mathrm{SD}$ & $\mathrm{CV}$ & $\mathbf{N}$ & $\operatorname{Avg} \pm \mathrm{SD}$ & $\mathrm{CV}$ \\
\hline Crude ash & 17 & $19.9 \pm 5.28$ & 26.6 & 11 & $25.2 \pm 2.57$ & 10.2 & 20 & $21.5 \pm 8.56$ & 39.8 \\
\hline Crude fat & 16 & $2.28 \pm 1.87$ & 81.9 & 7 & $3.94 \pm 2.29$ & 58.2 & 2 & $3.15 \pm 2.36$ & 74.9 \\
\hline Crude protein & 18 & $19.0 \pm 5.94$ & 31.3 & 14 & $7.56 \pm 2.63$ & 34.7 & 28 & $10.7 \pm 7.36$ & 69.0 \\
\hline $\begin{array}{c}\text { Carbohydrate } \\
\text { Minerals }\end{array}$ & 8 & $51.6 \pm 7.73$ & 15.0 & 2 & $62.9 \pm 6.75$ & 10.7 & 21 & $53.5 \pm 16.4$ & 30.7 \\
\hline Calcium & 5 & $24.5 \pm 19.7$ & 80.5 & 9 & $10.57 \pm 2.41$ & 22.8 & 7 & $39.6 \pm 38.9$ & 98.3 \\
\hline Magnesium & 3 & $23.0 \pm 5.30$ & 23.0 & 9 & $8.31 \pm 1.68$ & 20.2 & 7 & $6.79 \pm 0.69$ & 10.2 \\
\hline Phosphorus & 3 & $1.66 \pm 0.42$ & 25.2 & 8 & $1.96 \pm 1.98$ & 101 & 7 & $2.99 \pm 0.72$ & 23.9 \\
\hline Sodium & 4 & $18.0 \pm 7.35$ & 40.9 & 8 & $42.89 \pm 7.92$ & 18.5 & 7 & $46.0 \pm 4.93$ & 10.7 \\
\hline Potassium & 4 & $20.2 \pm 3.45$ & 17.1 & 9 & $33.20 \pm 21.3$ & 64.3 & 7 & $61.0 \pm 20.3$ & 33.3 \\
\hline Micro-minerals & & & & & & & & & \\
\hline Aluminum & 1 & 122 & & 4 & $89.2 \pm 69.7$ & 78.1 & 16 & $376 \pm 513$ & 137 \\
\hline Arsenic & 4 & $5.72 \pm 3.36$ & 58.7 & 4 & $37.5 \pm 11.8$ & 31.4 & 16 & $57.6 \pm 22.5$ & 39.1 \\
\hline Cadmium & 3 & $0.27 \pm 0.27$ & 101 & 4 & $0.95 \pm 0.58$ & 61.0 & 8 & $1.17 \pm 0.49$ & 41.5 \\
\hline Chromium & 3 & $2.66 \pm 1.19$ & 44.8 & 4 & $1.83 \pm 0.68$ & 37.4 & 8 & $0.61 \pm 0.50$ & 82.7 \\
\hline Cobalt & 3 & $1.06 \pm 0.57$ & 53.9 & 4 & $3.05 \pm 1.01$ & 33.2 & 7 & $0.16 \pm 0.10$ & 65.6 \\
\hline Copper & 6 & $30.0 \pm 52.4$ & 174 & 7 & $8.76 \pm 8.60$ & 98.2 & 16 & $2.41 \pm 1.09$ & 45.4 \\
\hline Iodine & 2 & $68.7 \pm 45.4$ & 66.1 & 1 & 461 & & 15 & $1549 \pm 1799$ & 116 \\
\hline Iron & 5 & $899 \pm 686$ & 76.3 & 8 & $185 \pm 88.1$ & 47.6 & 16 & $330 \pm 394$ & 119 \\
\hline Lead & 3 & $0.85 \pm 0.50$ & 59.0 & 4 & $0.49 \pm 0.01$ & 1.70 & 8 & $0.90 \pm 1.44$ & 159 \\
\hline Manganese & 5 & $47.4 \pm 41.0$ & 86.6 & 8 & $19.8 \pm 11.4$ & 57.3 & 16 & $14.6 \pm 12.4$ & 84.8 \\
\hline Nickel & 4 & $5.35 \pm 1.85$ & 34.5 & 4 & $1.85 \pm 0.67$ & 36.0 & 8 & $0.76 \pm 0.38$ & 50.4 \\
\hline Selenium & 2 & $1.07 \pm 0.88$ & 82.2 & 4 & $0.98 \pm 0.02$ & 1.70 & 7 & $1.60 \pm 1.38$ & 86.0 \\
\hline $\begin{array}{c}\text { Zinc } \\
E A A^{6}\end{array}$ & 5 & $26.5 \pm 19.7$ & 74.5 & 7 & $58.2 \pm 20.3$ & 35.0 & 16 & $34.9 \pm 17.1$ & 49.2 \\
\hline Histidine & 6 & $1.45 \pm 0.24$ & 16.3 & 3 & $1.32 \pm 0.16$ & 11.8 & 17 & $1.51 \pm 0.23$ & 14.9 \\
\hline Isoleucine & 6 & $3.49 \pm 0.83$ & 23.7 & 3 & $2.84 \pm 0.86$ & 30.5 & 17 & $2.68 \pm 1.11$ & 41.5 \\
\hline Leucine & 6 & $6.16 \pm 1.27$ & 20.6 & 3 & $4.80 \pm 1.82$ & 37.8 & 17 & $6.27 \pm 0.90$ & 14.4 \\
\hline Lysine & 6 & $4.14 \pm 1.22$ & 29.4 & 3 & $4.35 \pm 0.47$ & 10.9 & 17 & $4.23 \pm 1.17$ & 27.5 \\
\hline Methionine & 6 & $1.69 \pm 0.57$ & 33.8 & 3 & $1.34 \pm 0.65$ & 48.7 & 17 & $2.09 \pm 0.28$ & 13.4 \\
\hline Phenylalanine & 6 & $3.57 \pm 0.78$ & 21.7 & 3 & $3.04 \pm 1.29$ & 42.3 & 17 & $4.36 \pm 0.71$ & 16.3 \\
\hline
\end{tabular}


Table 3. Cont.

\begin{tabular}{|c|c|c|c|c|c|c|c|c|c|}
\hline \multirow[t]{2}{*}{ Item } & \multicolumn{3}{|c|}{ Ulva lactuca ${ }^{1}$} & \multicolumn{3}{|c|}{ Ascophyllum nodosum ${ }^{2}$} & \multicolumn{3}{|c|}{ Saccharina latissimi ${ }^{3}$} \\
\hline & $\mathbf{N}$ & $\operatorname{Avg} \pm \mathrm{SD}^{4}$ & $\mathrm{CV}^{5}$ & $\mathbf{N}$ & $\operatorname{Avg} \pm \mathrm{SD}$ & $\mathrm{CV}$ & $\mathbf{N}$ & $\operatorname{Avg} \pm \mathrm{SD}$ & $\mathrm{CV}$ \\
\hline Threonine & 6 & $4.59 \pm 1.08$ & 23.5 & 3 & $3.47 \pm 1.09$ & 31.3 & 17 & $4.57 \pm 0.42$ & 9.10 \\
\hline Tryptophan & & & & 1 & 0.14 & & 6 & $1.74 \pm 0.22$ & 12.9 \\
\hline $\begin{array}{l}\text { Valine } \\
N E A A^{7}\end{array}$ & 6 & $5.79 \pm 1.75$ & 30.2 & 3 & $3.56 \pm 1.12$ & 31.5 & 17 & $4.19 \pm 0.76$ & 18.2 \\
\hline Arginine & 6 & $4.89 \pm 0.94$ & 19.2 & 3 & $3.13 \pm 0.99$ & 31.8 & 17 & $5.33 \pm 1.11$ & 20.9 \\
\hline Alanine & 5 & $1.19 \pm 0.60$ & 50.3 & 4 & $4.59 \pm 3.24$ & 70.6 & 17 & $11.6 \pm 3.01$ & 25.9 \\
\hline Aspartic acid & 6 & $10.1 \pm 2.78$ & 27.6 & 4 & $6.42 \pm 3.18$ & 49.5 & 17 & $15.3 \pm 3.89$ & 25.4 \\
\hline Cysteine & 5 & $2.27 \pm 1.90$ & 83.5 & 1 & 1.80 & & 17 & $6.82 \pm 6.20$ & 90.9 \\
\hline Glutamic acid & 6 & $10.3 \pm 1.87$ & 18.1 & 4 & $10.1 \pm 6.84$ & 67.8 & 17 & $17.5 \pm 3.81$ & 21.8 \\
\hline Glycine & 6 & $6.07 \pm 2.26$ & 37.2 & 2 & $4.85 \pm 0.05$ & 1.02 & 17 & $8.56 \pm 2.57$ & 30.0 \\
\hline Proline & 6 & $4.03 \pm 0.83$ & 20.6 & 4 & $2.66 \pm 1.72$ & 64.6 & 17 & $4.89 \pm 2.08$ & 42.5 \\
\hline Serine & 6 & $4.72 \pm 1.37$ & 29.1 & 3 & $4.19 \pm 0.15$ & 3.46 & 17 & $5.93 \pm 1.32$ & 22.3 \\
\hline Tyrosine & 4 & $2.96 \pm 1.78$ & 60.3 & 2 & $1.37 \pm 0.50$ & 36.8 & 16 & $1.96 \pm 1.18$ & 60.2 \\
\hline$\sum \mathrm{AA}$ & 6 & 83.0 & & 3 & 66.8 & & 17 & 108 & \\
\hline$\overline{\sum E A A}$ & 6 & 30.9 & & 3 & 24.8 & & 17 & 30.5 & \\
\hline ¿NEAA & 6 & 52.1 & & 3 & 42.1 & & 17 & 77.8 & \\
\hline EAA:NEAA & 6 & 0.60 & & 3 & 0.61 & & 17 & 0.42 & \\
\hline
\end{tabular}

${ }^{1}$ Based on literature values: [89-108]; ${ }^{2}$ Based on literature values: [84,88,109-117]; ${ }^{3}$ Based on literature values: $[36,84,87,92,102,103,118,119]$;

${ }^{4}$ Average \pm standard deviation over included studies; ${ }^{5}$ Coefficient of variation over included studies; ${ }^{6}$ Essential amino acids; ${ }^{7}$ Nonessential amino acids.

\subsection{Insect Meal as Compared to Soya Bean}

Nutrient composition of insect larvae meals is shown in Table 4. Black soldier fly is depicted in full fat as well as in defatted form. Black soldier fly contains the most ash, and the mineral composition differs from that in yellow and lesser mealworm. Calcium is almost 10-fold more abundant in black soldier fly than in either of the two mealworms. Phosphorus is the next most abundant mineral in black soldier fly and is similar among all insect meals. Therefore, there is a wider Ca:P ratio in black soldier fly compared to the other insect meals. Chitin and ADF levels vary between and within insect species. The acid detergent fiber (ADF) fraction of insects is believed to be representative of the chitin derived from the insect cuticle, i.e., part of the exoskeleton [120]. The level of chitin in insect meal is of importance because it can negatively affect protein digestibility as some AA in insect meal are bound to chitin $[120,121]$. The protein concentration in insect meal, with the exception of full fat black soldier fly, is higher than that in soya bean. The lower protein concentration in full fat black soldier fly is due to the high fat content. Fat in black soldier fly can reach levels of up to $40 \%$ of DM [122]. The variation in crude fat content for defatted black soldier fly is due to varying degrees of processing. Insects have an EAA:NEAA ratio similar to or higher than that observed in soya bean. The most abundant EAA is leucine for all insect types. This is also the most abundant EAA in soya bean. Furthermore, lysine and valine are highly abundant in insect meals. The range of most EAA in insect meals is similar to values observed for EAA in soya bean. Phenylalanine, however, is lower in insect meals than in soya bean. The ratio between phenylalanine and lysine of the insects (0.59-0.74:1) is equal or above the established ideal ratio to meet minimum requirements for pigs $[68,123]$ and should therefore not restrict feed formulation. Finally, several studies find low values of cysteine, i.e., below $1 \mathrm{~g} / 100 \mathrm{~g} \mathrm{CP}$, in the different insect meals. Sufficient levels of cysteine are important in order to balance methionine and cysteine in diet formulations. Sulphur-containing amino acids are often difficult to supply at adequate levels in organic diet formulations [124]. Hence, the quality of insect meal may be variable depending on the level of cysteine and methionine. The variation within AAs is stronger for all insect meals than for soya bean. Rearing substrate may be one important determinant for insects' nutrient composition [20,125]. Knowledge on variation in AA composition and chitin bound $\mathrm{N}$ will be particularly useful as this determines protein quality. It will be useful to better understand factors at rearing and processing that affect the nutrient composition and protein quality of insect meals when using them in animal 
feed, and, as for most other new feed ingredients, an analysis of nutrient composition will be valuable before diets are composed.

Table 4. Chemical composition of macronutrients (g/100 g DM), minerals (g/kg DM), and amino acid (AA) profile (g/100 g CP) in Tenebrio molitor (yellow mealworm), Alphitobius diaperinus (lesser mealworm), and Hermetia illucens (black soldier fly).

\begin{tabular}{|c|c|c|c|c|c|c|c|c|c|c|c|c|}
\hline \multirow[t]{2}{*}{ Item } & \multicolumn{3}{|c|}{ Tenebrio molitor ${ }^{1}$} & \multicolumn{3}{|c|}{ Alphitobius diaperinus ${ }^{2}$} & \multicolumn{3}{|c|}{ Full Fat Hermetia illucens ${ }^{3}$} & \multicolumn{3}{|c|}{ Defatted Hermetia illucens ${ }^{4}$} \\
\hline & $\mathbf{N}$ & $\operatorname{Avg} \pm S^{5}$ & $\mathrm{CV}^{6}$ & $\mathbf{N}$ & $\operatorname{Avg} \pm \mathrm{SD}$ & $\mathrm{CV}$ & $\mathbf{N}$ & $\operatorname{Avg} \pm \mathrm{SD}$ & $\mathrm{CV}$ & $\mathbf{N}$ & $\operatorname{Avg} \pm \mathrm{SD}$ & $\mathrm{CV}$ \\
\hline Crude ash & 13 & $4.15 \pm 0.65$ & 15.6 & 5 & $4.47 \pm 0.69$ & 15.4 & 15 & $6.56 \pm 2.99$ & 45.5 & 9 & $9.30 \pm 3.27$ & 35.2 \\
\hline Crude fat & 14 & $27.0 \pm 6.59$ & 24.4 & 7 & $22.0 \pm 4.87$ & 22.1 & 16 & $34.3 \pm 6.66$ & 19.4 & 11 & $12.1 \pm 6.25$ & 51.5 \\
\hline Crude protein & 15 & $56.0 \pm 4.75$ & 8.50 & 8 & $59.7 \pm 10.7$ & 18.0 & 17 & $43.1 \pm 5.05$ & 11.7 & 11 & $56.7 \pm 7.16$ & 12.6 \\
\hline ADF & 5 & $8.43 \pm 1.12$ & 13.2 & 1 & 8.02 & & 2 & $7.40 \pm 0.12$ & 1.69 & 3 & $7.85 \pm 3.25$ & 41.4 \\
\hline Chitin & 4 & $5.02 \pm 0.33$ & 6.51 & 1 & 4.60 & & 4 & $3.67 \pm 1.07$ & 29.3 & 6 & $6.11 \pm 2.14$ & 35.0 \\
\hline $\begin{array}{c}\text { Crude fiber } \\
\text { Minerals }\end{array}$ & 4 & $8.20 \pm 1.96$ & 23.9 & 2 & $7.43 \pm 0.14$ & 1.92 & 7 & $7.35 \pm 3.04$ & 41.4 & 1 & 7.16 & \\
\hline Calcium & 2 & $0.44 \pm 0.12$ & 28.2 & 3 & $0.50 \pm 0.16$ & 32.2 & 10 & $24.1 \pm 12.8$ & 53.2 & 4 & $38.0 \pm 29.5$ & 77.5 \\
\hline Phosphorus & 4 & $7.80 \pm 0.85$ & 10.9 & 3 & $8.20 \pm 0.73$ & 8.95 & 10 & $6.01 \pm 1.77$ & 29.5 & 4 & $6.05 \pm 3.19$ & 52.7 \\
\hline $\begin{array}{l}\text { Sodium } \\
E A A^{7}\end{array}$ & 2 & $1.05 \pm 0.24$ & 23.0 & 2 & $2.21 \pm 0.21$ & 9.40 & 7 & $0.69 \pm 0.21$ & 30.0 & 3 & $0.75 \pm 0.48$ & 64.2 \\
\hline Histidine & 9 & $3.09 \pm 0.56$ & 18.2 & 7 & $4.32 \pm 1.35$ & 31.2 & 10 & $3.12 \pm 0.52$ & 16.8 & 8 & $2.68 \pm 0.43$ & 16.1 \\
\hline Isoleucine & 8 & $4.25 \pm 0.81$ & 19.1 & 7 & $4.35 \pm 0.33$ & 7.50 & 10 & $4.37 \pm 0.46$ & 10.5 & 9 & $4.05 \pm 0.58$ & 14.4 \\
\hline Leucine & 8 & $6.76 \pm 1.17$ & 17.4 & 7 & $6.64 \pm 0.43$ & 6.50 & 10 & $6.72 \pm 0.57$ & 8.40 & 9 & $6.41 \pm 0.92$ & 14.4 \\
\hline Lysine & 9 & $5.60 \pm 1.09$ & 19.5 & 7 & $5.94 \pm 1.04$ & 17.5 & 10 & $6.22 \pm 1.08$ & 17.3 & 10 & $5.80 \pm 1.52$ & 26.3 \\
\hline Methionine & 9 & $1.38 \pm 0.37$ & 26.7 & 6 & $1.59 \pm 0.54$ & 34.1 & 10 & $1.93 \pm 0.32$ & 16.5 & 10 & $1.61 \pm 0.53$ & 32.9 \\
\hline Phenylalanine & 8 & $3.65 \pm 0.64$ & 17.6 & 6 & $4.41 \pm 0.46$ & 10.4 & 10 & $4.19 \pm 0.37$ & 8.90 & 7 & $3.41 \pm 0.35$ & 10.3 \\
\hline Threonine & 8 & $3.81 \pm 0.59$ & 15.6 & 6 & $3.99 \pm 0.33$ & 8.20 & 10 & $4.19 \pm 0.37$ & 9.00 & 10 & $3.80 \pm 0.62$ & 16.3 \\
\hline Tryptophan & 3 & $1.07 \pm 0.38$ & 35.5 & 5 & $1.16 \pm 0.40$ & 34.6 & 7 & $1.86 \pm 0.18$ & 9.60 & 5 & $0.82 \pm 0.25$ & 30.0 \\
\hline $\begin{array}{c}\text { Valine } \\
N E A A^{8}\end{array}$ & 8 & $5.85 \pm 0.98$ & 16.8 & 7 & $5.72 \pm 0.41$ & 7.20 & 10 & $5.38 \pm 0.82$ & 15.3 & 9 & $6.46 \pm 2.04$ & 31.6 \\
\hline Arginine & 8 & $5.55 \pm 1.12$ & 20.2 & 7 & $5.57 \pm 0.73$ & 13.1 & 9 & $4.93 \pm 0.68$ & 13.8 & 8 & $5.06 \pm 1.88$ & 37.1 \\
\hline Alanine & 7 & $6.81 \pm 0.89$ & 13.1 & 6 & $7.02 \pm 1.35$ & 19.2 & 10 & $6.6 \pm 1.14$ & 17.3 & 4 & $6.90 \pm 0.72$ & 10.5 \\
\hline Aspartic acid & 8 & $6.67 \pm 2.60$ & 39.0 & 6 & $8.30 \pm 0.67$ & 8.00 & 10 & $8.86 \pm 0.83$ & 9.30 & 4 & $7.27 \pm 0.80$ & 11.0 \\
\hline Cysteine & 7 & $1.14 \pm 0.81$ & 71.3 & 5 & $1.03 \pm 0.25$ & 24.6 & 9 & $1.51 \pm 1.79$ & 119 & 9 & $0.50 \pm 0.32$ & 63.6 \\
\hline Glutamic acid & 7 & $10.8 \pm 1.56$ & 14.4 & 6 & $12.4 \pm 1.12$ & 9.00 & 10 & $10.7 \pm 1.57$ & 14.7 & 4 & $10.5 \pm 1.30$ & 12.3 \\
\hline Glycine & 8 & $7.29 \pm 5.92$ & 81.2 & 6 & $4.40 \pm 0.22$ & 4.90 & 10 & $5.14 \pm 0.44$ & 8.60 & 4 & $4.51 \pm 0.17$ & 3.86 \\
\hline Proline & 7 & $6.31 \pm 1.16$ & 18.4 & 6 & $5.89 \pm 0.52$ & 8.90 & 9 & $5.82 \pm 1.68$ & 28.8 & 5 & $4.91 \pm 0.92$ & 18.7 \\
\hline Serine & 7 & $4.14 \pm 0.73$ & 17.6 & 6 & $4.12 \pm 0.39$ & 9.40 & 10 & $4.20 \pm 0.58$ & 13.9 & 4 & $3.88 \pm 0.20$ & 5.13 \\
\hline Tyrosine & 7 & $6.23 \pm 1.33$ & 21.3 & 5 & $7.76 \pm 0.49$ & 6.30 & 6 & $6.74 \pm 1.96$ & 29.1 & 5 & $4.94 \pm 0.84$ & 16.9 \\
\hline$\sum \mathrm{AA}$ & 7 & 88.0 & & 6 & 91.3 & & 10 & 88.4 & & 4 & 79.4 & \\
\hline$\sum \mathrm{EAA}$ & 7 & 34.5 & & 7 & 36.4 & & 10 & 37.4 & & 5 & 31.1 & \\
\hline ENEAA & 7 & 53.5 & & 6 & 55.2 & & 10 & 50.6 & & 4 & 48.1 & \\
\hline EAA:NEAA & 7 & 0.64 & & 6 & 0.66 & & 6 & 0.69 & & 3 & 0.67 & \\
\hline
\end{tabular}

${ }^{1}$ Based on literature values: [121,126-138]; ${ }^{2}$ Based on literature values: [130,139-145]; ${ }^{3}$ Based on literature values: [39,40,121,122,128,129, 146-150]; ${ }^{4}$ Based on literature values: $[138,148,151-156] ;{ }^{5}$ Average \pm standard deviation over included studies; ${ }^{6}$ Coefficient of variation over included studies; ${ }^{7}$ Essential amino acids; ${ }^{8}$ Non-essential amino acids.

\subsection{Grass Protein Meal as Compared to Soya Bean}

The nutrient composition of green protein extracted from perennial ryegrass (Lollium perenne), lucerne (Medicago sativa L.), and red clover (Trifolium pretense L.) is shown in Table 5. Green protein produced by various biorefining methods is included, and here focus is on studies where amino acid data are available. Lucerne has previously been the forage crop of choice; however, especially in more temperate climates in Northern Europe, perennial crops like red clover and ryegrass are promising as biomass input for the biorefining process. The crude protein content of the green protein is highly dependent on process parameters: $[157,158]$ making a direct comparison of published contents challenging. Green protein from legumes generally has a higher crude protein content than green protein extracted from grass species, levelling with soya bean meal. The crude protein in the input biomass is usually higher in legumes than in grasses, which, combined with a higher extraction efficiency in legumes [44], is expected to result in the high crude protein content of legume green protein. The amino acid composition in green protein from lucerne, red clover, and ryegrass is very similar with minor species differences within both the essential and non-essential amino acids. The conserved enzyme Rubisco 
constitutes the majority of protein in plant leaves and therefore also in green protein [159]. The result is limited species variation in the amino acid composition [160]. Green protein has an EAA:NEAA ratio which for the legumes is higher than values in soya bean and fishmeal. The most abundant essential amino acid in green protein is leucine as seen with the insects and soya bean. The content of lysine, the first limiting amino acid in grain-based pig feed, is lower in green protein than corresponding values in fish meal and soya bean. Generally, the lysine content in protein from legumes is higher than values in ryegrass; however, low values in data from Baraniak [161] decrease the table average. Damborg et al. [44], Stødkilde et al. [160] presented higher values in red clover, white clover, and lucerne than in perennial ryegrass. The sulphur-containing amino acids methionine and cysteine are the limiting amino acids in protein extracted from green forage crops [160,162] Although, green protein methionine content is exceeding soya bean methionine content, the content of cysteine in green protein is lower than in soya bean and fishmeal, making the content of sulphur-containing amino acids insufficient for poultry and pigs [68,160,163]. Green protein from ryegrass has a higher content of methionine compared to the legumes. In a grass-clover mixture, which is commonly used on arable land in Northern Europe, a large proportion of ryegrass would contribute positively to the overall methionine content.

Table 5. Chemical composition of macronutrients (g/100 g DM) and amino acids (g/100 g CP) in green protein from perennial ryegrass (Lolium perenne), lucerne (Medicago sativa L.), and red clover (Trifolium pretense L.) ${ }^{1}$.

\begin{tabular}{|c|c|c|c|c|c|c|c|c|c|}
\hline \multirow[t]{2}{*}{ Item } & \multicolumn{3}{|c|}{ Ryegrass } & \multicolumn{3}{|c|}{ Lucerne } & \multicolumn{3}{|c|}{ Red Clover } \\
\hline & $\mathbf{N}$ & $\operatorname{Avg} \pm S^{2}$ & $\mathrm{CV}^{3}$ & $\mathbf{N}$ & $\operatorname{Avg} \pm \mathrm{SD}$ & $\mathrm{CV}$ & $\mathbf{N}$ & $\operatorname{Avg} \pm \mathrm{SD}$ & $\mathrm{CV}$ \\
\hline Crude ash & & & & 6 & $10.7 \pm 6.56$ & 61.3 & 7 & $11.7 \pm 4.58$ & 39.9 \\
\hline $\begin{array}{c}\text { Crude protein } \\
E A A^{4}\end{array}$ & 3 & $28.4 \pm 7.13$ & 25.1 & 10 & $47.4 \pm 10.7$ & 15.7 & 3 & $38.7 \pm 5.35$ & 13.8 \\
\hline Histidine & 3 & $2.02 \pm 0.17$ & 8.48 & 7 & $2.21 \pm 0.18$ & 8.10 & 9 & $2.29 \pm 0.29$ & 12.5 \\
\hline Isoleucine & 3 & $4.74 \pm 0.36$ & 7.50 & 7 & $4.50 \pm 0.72$ & 16.0 & 10 & $4.88 \pm 0.64$ & 13.1 \\
\hline Leucine & 3 & $8.43 \pm 0.53$ & 6.32 & 7 & $7.74 \pm 1.15$ & 14.9 & 10 & $8.54 \pm 0.98$ & 11.4 \\
\hline Lysine & 3 & $5.48 \pm 0.56$ & 10.2 & 7 & $4.95 \pm 1.17$ & 23.6 & 10 & $5.70 \pm 0.92$ & 16.1 \\
\hline Methionine & 3 & $2.04 \pm 0.19$ & 9.31 & 7 & $1.76 \pm 0.22$ & 12.5 & 10 & $1.85 \pm 0.27$ & 14.7 \\
\hline Phenylalanine & 3 & $6.17 \pm 0.95$ & 15.3 & 7 & $5.54 \pm 0.65$ & 11.8 & 10 & $5.57 \pm 0.76$ & 13.7 \\
\hline Threonine & 3 & $4.65 \pm 0.33$ & 7.00 & 7 & $4.16 \pm 0.78$ & 18.8 & 10 & $4.66 \pm 0.61$ & 13.0 \\
\hline Tryptophan & - & - & - & - & - & - & - & - & - \\
\hline $\begin{array}{l}\text { Valine } \\
N E A A^{5}\end{array}$ & 3 & $6.27 \pm 0.54$ & 8.56 & 7 & $5.21 \pm 0.97$ & 18.6 & 10 & $6.01 \pm 0.66$ & 11.0 \\
\hline Alanine & 2 & $6.73 \pm 0.70$ & 10.4 & 4 & $5.70 \pm 0.55$ & 9.73 & 9 & $5.80 \pm 0.61$ & 10.5 \\
\hline Arginine & 3 & $5.73 \pm 0.39$ & 6.81 & 7 & $4.61 \pm 1.43$ & 31.0 & 10 & $5.54 \pm 0.77$ & 13.9 \\
\hline Aspartic acid & 2 & $8.72 \pm 0.70$ & 8.03 & 5 & $9.24 \pm 2.01$ & 21.7 & 9 & $10.2 \pm 1.72$ & 16.9 \\
\hline Cysteine & 3 & $0.83 \pm 0.11$ & 13.6 & 7 & $0.99 \pm 0.21$ & 21.0 & 9 & $0.67 \pm 0.24$ & 36.0 \\
\hline Glutamic acid & 2 & $9.74 \pm 0.79$ & 8.13 & 5 & $8.62 \pm 1.40$ & 16.2 & 9 & $10.6 \pm 1.65$ & 15.6 \\
\hline Glycine & 3 & $5.42 \pm 0.31$ & 5.64 & 7 & $4.58 \pm 0.83$ & 18.1 & 10 & $5.16 \pm 0.64$ & 12.5 \\
\hline Proline & 2 & $4.63 \pm 0.46$ & 9.94 & 7 & $3.27 \pm 0.83$ & 22.3 & 9 & $4.51 \pm 0.26$ & 5.84 \\
\hline Serine & 3 & $4.34 \pm 0.20$ & 4.56 & 7 & $4.72 \pm 0.52$ & 10.9 & 10 & $4.31 \pm 0.41$ & 9.61 \\
\hline Tyrosine & - & - & - & 1 & 1.91 & & 3 & $4.25 \pm 0.92$ & 21.6 \\
\hline Met+Cys & 3 & $2.87 \pm 0.30$ & 22.9 & 7 & $2.75 \pm 0.28$ & 33.4 & 9 & $2.45 \pm 0.56$ & 22.9 \\
\hline$\sum \mathrm{AA}$ & & 85.92 & & & 80.15 & & & 90.49 & \\
\hline$\sum E A A$ & & 39.80 & & & 36.06 & & & 39.50 & \\
\hline ¿NEAA & & 46.13 & & & 44.09 & & & 50.99 & \\
\hline EAA:NEAA & & 0.86 & & & 0.82 & & & 0.77 & \\
\hline
\end{tabular}

${ }^{1}$ Based on data from $[4,160,161,164-171] ;{ }^{2}$ Average \pm standard deviation over included studies; ${ }^{3}$ Coefficient of variation over included studies; ${ }^{4}$ Essential amino acids; ${ }^{5}$ Non-essential amino acids.

Data on the mineral composition of green protein from grasses and legumes are very limited. However, the methods by which proteins are isolated from green juice seem to influence the mineral content of the green protein. Baraniak [161] demonstrated that the green protein from lucerne was characterized by a high content of macro- and microelements, generally exceeding the values in the lucerne plant; however, precipitating the proteins with acidification led to a low content of calcium and potassium, likely due to the minerals being distributed to the brown juice. 


\section{Animal Studies}

In this section, studies that focus on feeding monogastric animals with meal from mussel, starfish, seaweed, insects, and forage crop protein extract will be discussed in terms of nutrient digestibility and animal performance, i.e., gain, feed intake and feed efficiency. Studies that have used conventional as well as organic monogastric production will be reviewed. Studies using conventionally held monogastrics can give an insight into the potential and limitations of alternative feed ingredients to replace high protein feed ingredients, soya bean, and fishmeal, which can be useful for organic production as well. This indicates whether they can be considered high quality protein and therefore be used to fulfil protein and amino acid requirements in organic monogastric nutrition. However, it should be taken into account that crystalline AA are used in conventional diets. Moreover, in organic animal husbandry, slow-growing breeds with generally lower nutrient requirements are used [124]. The number of studies on the reviewed feed ingredients that use slow-growing, organic monogastrics is, however, limited.

\subsection{Mussel Meal and Starfish Meal}

\subsubsection{Digestibility}

The standardized ileal digestibility of protein from both deshelled mussel meal and starfish meal has been evaluated in growing pigs [74]. A standardized ileal digestibility coefficient of 0.83 was obtained for crude protein from mussel meal, and comparable standardized ileal digestibility coefficients were found for AA. Similarly, starfish meal had a standardized ileal CP digestibility coefficient of 0.80 . This indicates that protein from mussel and starfish meal will be highly available for growth. Fishmeal is characterized as having an apparent ileal $\mathrm{N}$ digestibility of 0.82 in growing pigs [172] and a standardized ileal CP digestibility of 0.84 in weaned pigs [173]. No studies have looked at the specific digestibility of mussel meal or starfish meal as a feed ingredient in poultry. Nevertheless, the digestibility of diets containing up to $12 \%$ mussel meal has been investigated in laying hens. Diets containing 4, 8, or $12 \%$ mussel meal compared with $3.7 \%$ fishmeal were found to give higher apparent excreta digestibility of fat but did not change digestibility of organic matter in laying hens. These results point to mussel meal in diets being as digestible as fishmeal. This would also be expected based on the comparable nutrient composition with fishmeal.

\subsubsection{Growth Performance Mussel Meal}

An overview of animal performance studies using mussel meal and starfish meal is presented in Table 6 .

Table 6. Summary of performance characteristics of monogastric animals fed varying inclusion levels of starfish meal or mussel meal.

\begin{tabular}{|c|c|c|c|c|c|c|}
\hline Type & Inclusion \% & Control & Animal/Breed & Parameters & Effect & Reference \\
\hline Starfish & 4,8 & Fishmeal, Org. ${ }^{1}$ & $\begin{array}{l}\text { Laying hen/ } \\
\text { Hisex white }\end{array}$ & $\begin{array}{l}\text { Bird weight, } \\
\text { FCR }^{2}, \\
\text { ADFI }^{3} \\
\text { Egg weight, } \\
\text { Laying \% }\end{array}$ & $\begin{array}{l}\text { No effect } \\
\text { No effect } \\
\text { No effect } \\
\text { No effect } \\
\text { No effect }\end{array}$ & [174] \\
\hline Starfish & $0,5,10$ & Fishmeal & $\begin{array}{c}\text { Weaned pig/ } \\
\text { Danish } \\
\text { Landrace/Yorkshire } \times \\
\text { Duroc }\end{array}$ & $\begin{array}{l}\mathrm{ADG}^{4}, \\
\text { FCR, } \\
\text { ADFI, }\end{array}$ & $\begin{array}{c}\text { Reduced } 10 \\
\text { Worsened } 10 \\
\text { No effect }\end{array}$ & [63] \\
\hline Starfish & $0,5,7.5,10$ & Fishmeal & $\begin{array}{c}\text { Weaned pig/ } \\
\text { Danish } \\
\text { Landrace/Yorshire } \times \\
\text { Duroc }\end{array}$ & $\begin{array}{l}\text { FCR, } \\
\text { ADG, } \\
\text { ADFI }\end{array}$ & $\begin{array}{l}\text { Worsened 7.5, } 10 \\
\text { Reduced 7.5, } 10 \\
\text { No effect }\end{array}$ & [78] \\
\hline
\end{tabular}


Table 6. Cont.

\begin{tabular}{|c|c|c|c|c|c|c|}
\hline Type & Inclusion \% & Control & Animal/Breed & Parameters & Effect & Reference \\
\hline Mussel & $0,4,8,12$ & $\begin{array}{l}\text { Fishmeal, } \\
\text { Org. }\end{array}$ & $\begin{array}{l}\text { Laying hen/ } \\
\text { Hisex white }\end{array}$ & $\begin{array}{c}\text { ADFI, } \\
\text { FCR, } \\
\text { Egg weight, } \\
\text { Laying \% }\end{array}$ & $\begin{array}{l}\text { No effect } \\
\text { No effect } \\
\text { No effect } \\
\text { No effect }\end{array}$ & {$[174]$} \\
\hline Mussel & $0,3,6,9$ & $\begin{array}{l}\text { Fishmeal, } \\
\text { Org. }\end{array}$ & $\begin{array}{c}\text { Laying hen/ } \\
\text { Lohmann Selected } \\
\text { leghorn }\end{array}$ & $\begin{array}{c}\text { FCR, } \\
\text { Egg weight, } \\
\text { Laying \% }\end{array}$ & $\begin{array}{l}\text { No effect } \\
\text { No effect } \\
\text { No effect }\end{array}$ & {$[75]$} \\
\hline Mussel & $0,3.5,7.0$ & $\begin{array}{l}\text { Fishmeal, } \\
\text { Org. }\end{array}$ & $\begin{array}{c}\text { Laying hen/ } \\
\text { Lohmann Selected } \\
\text { leghorn and Hyline white } \\
\text { W-98 }\end{array}$ & $\begin{array}{l}\text { ADFI, } \\
\text { Bird weight, } \\
\text { FCR, } \\
\text { Egg weight, } \\
\text { Laying \% }\end{array}$ & $\begin{array}{l}\text { No effect } \\
\text { No effect } \\
\text { No effect } \\
\text { No effect } \\
\text { No effect }\end{array}$ & [175] \\
\hline Mussel & $0,3,6,9,12$ & Fishmeal & $\begin{array}{c}\text { Broiler/ } \\
\text { Ross } 308\end{array}$ & $\begin{array}{c}\text { ADFI, } \\
\text { FCR, } \\
\text { Bird weight }\end{array}$ & $\begin{array}{l}\text { No effect } \\
\text { No effect } \\
\text { No effect }\end{array}$ & [176] \\
\hline Mussel & 0,5 & Commercial diet & $\begin{array}{c}\text { Grower-finisher pig/ } \\
\text { Yorkshire } \times \text { Hampshire } \times \\
\text { Duroc }\end{array}$ & ADG & No effect & [177] \\
\hline
\end{tabular}

${ }^{1}$ Organic diet; ${ }^{2}$ Feed conversion ratio, i.e., $\mathrm{kg}$ feed $/ \mathrm{kg}$ gain for growing animals and $\mathrm{kg}$ feed $/ \mathrm{kg}$ egg for laying hens; ${ }^{3}$ Average daily feed intake; ${ }^{4}$ Average daily gain.

In accordance with the observation of high available protein, Wallenbeck et al. [177] found that including $5 \%$ deshelled mussel meal in diets for grower-finisher pigs gave similar weight gain compared with feeding a commercial diet. There is an overall agreement among studies using mussel meal for laying hens that there is no difference in growth performance or egg laying performance when feeding organic diets containing fishmeal or between $3 \%$ and $12 \%$ mussel meal $[75,174,175]$. Furthermore, there is an overall agreement that egg quality is not altered when feeding mussel meal instead of fishmeal in terms of egg weight, shell strength, or deformation, and albumen weight and height. Yolk pigmentation is found to be more orange when feeding mussel meal [174]. This effect is related to the high carotenoid levels in mussel meal. One study has been performed using conventional broiler chicks in which birds were fed no mussel meal or fishmeal, or diets with 3,6 , 9, or $12 \%$ of either fishmeal or mussel meal [176]. None of these inclusion levels were found to have affected feed intake, live weight, or feed conversion ratio (FCR) of broilers. A limiting factor for the inclusion of mussel and starfish meal could be an off-flavor and an off-odor. Indeed, $12 \%$ mussel meal was found to give a fishy taint, which was hypothesized to be due to an accumulation of methylamine [174]. However, it will still be possible to completely substitute fishmeal in commercial diets because inclusion rate of fishmeal is usually below $5 \%$. Since blue mussels are filter feeders, the uptake of water contaminants may affect safety and toxicity of mussel meal $[69,178]$. Similarly, starfish, who mainly feed on mussels, could be affected. In the EU, however, the quality of shellfish water is regulated continuously because of EU Directive 2006/113/EC [179]. Moreover, Jönsson and Holm [180] fed either 15\% normal mussel meal or 15\% mussel meal with high levels of the diarrheic shellfish toxin, okadaic acid, or a commercial diet to conventionally held laying hens and found no difference in growth and egg laying performance of hens. The level of okadaic acid in egg yolk was moreover not different between diets.

\subsubsection{Growth Performance Starfish Meal}

In a two-week study, Sørensen and Nørgaard [63] showed that including 5\% starfish meal in weaned pigs' diets gave similar daily gain and feed efficiency compared with similar levels of fishmeal or extruded soya bean. On the other hand, increasing the inclusion level to $10 \%$ reduced both gain and feed efficiency. This can be related to a high calcium concentration in starfish meal. Excess calcium can limit the availability of phosphorus by binding phytate, competing for the active sites of phytase or by increasing intestinal pH and thereby reducing enzyme efficacy [181,182]. Indeed, phosphorus levels 
in plasma of pigs fed $10 \%$ starfish meal compared with pigs fed fishmeal or $5 \%$ starfish meal were reduced [63]. Phosphorus is important for growth as it plays a role in energy metabolism, cell differentiation, and bone development [183,184]. Additionally, the unabsorbed phosphorus will be excreted into the environment. In a subsequent study at a commercial setting, the same conclusions were obtained when including $5,7.5$, or $10 \%$ starfish meal in diets of newly weaned conventionally held pigs in which $7.5 \%$ starfish meal also lowered gain and feed efficiency [78]. Higher levels of starfish meal can likely be included in laying hen ratios. It was indeed found that bodyweight, FCR, and feed intake of laying hens were unaltered by the inclusion of either 4 or $8 \%$ starfish meal as a fishmeal substitute [175]. Moreover, egg laying rate and egg weight did not differ when feeding starfish meal or fishmeal [175]. Although, layers can consume high levels of calcium to sustain egg production, the inclusion ratio of starfish meal in complete feed will still be limited by the calcium content. The requirement for high levels of calcium is, namely, time dependent, and calcium included above the required level, and outside the period of egg shell formation, may not be effectively utilized by laying hens, therefore risking higher excretion of phosphorus as a result of bone mineralization [185].

\subsection{Insect Meal}

\subsubsection{Digestibility}

The effect of insect-containing diets on digestibility is summarized in Table 7.

Table 7. Nutrient digestibility of monogastrics' diets containing varying inclusion levels of insect meals (Hermetia illucens, $\mathrm{HI}$ and Tenebrio molitor, TM) as compared to a basal diet or diets containing soya bean.

\begin{tabular}{|c|c|c|c|c|c|c|c|}
\hline Nutrient & Insect & Inclusion \% & Control & Animal & Description & Effect Insect & Reference \\
\hline $\begin{array}{c}\text { CP, fat, } \\
\mathrm{DM} / \mathrm{OM}\end{array}$ & HI defat. & $0,5,10$ & Soya bean & Weaned pig & ATTD $^{1}$ & No effect & [186] \\
\hline $\begin{array}{c}\text { CP, fat, } \\
\mathrm{DM} / \mathrm{OM}\end{array}$ & HI full/defat. & $4-8$ & Soya bean & Weaned pig & ATTD/AID ${ }^{2}$ & No effect & [187] \\
\hline $\mathrm{DM} / \mathrm{OM}$ & HI defat. & $0,7.3,14.6$ & Soya bean & Laying hen & AID & Reduced at 14.6 & [188] \\
\hline $\mathrm{CP}, \mathrm{DM} / \mathrm{OM}$ & HI defat. & 17 & Soya bean & Laying hen & AID & Reduced & [151] \\
\hline $\mathrm{CP}$ & $\begin{array}{l}\text { HI defat. } \\
\text { (Met:Cys } \\
\text { balanced) }\end{array}$ & 20 & Soya bean & Broiler & AID & No effect & [152] \\
\hline $\mathrm{CP}$ & HI full/defat. & 25 & Basal & Broiler & ATTD & Reduced & [189] \\
\hline AA & $\mathrm{TM}$ & $0,5,10$ & Soya bean & Growing pig & Ileal dig. & Reduced at 10 & [190] \\
\hline $\mathrm{CP}, \mathrm{DM} / \mathrm{OM}$ & TM & 30 & Soya bean & Broilers & AID & Reduced & [126] \\
\hline
\end{tabular}

Several studies suggest that the effect of insects on digestibility is dose-dependent. Both Biasato et al. [186] and Spranghers et al. [187] found that apparent total tract digestibility of dry matter, organic matter, crude protein, and crude fat was not different when feeding between $4 \%$ and $10 \%$ black soldier fly larvae or soya bean to newly weaned pigs. The same conclusions were drawn for digestibility of nutrients in the ileum [187]. Furthermore, numerically lower AA digestibilities were found when feeding growing pigs $10 \%$, but not $5 \%$, yellow mealworm compared to soya bean [190]. In line with this, at $14.6 \%$ compared to 7.3 or $0 \%$ inclusion of defatted black soldier fly, the apparent ileal $\mathrm{DM}$ and organic matter (OM) digestibilities were lowered in laying hens [188]. The CP digestibility reduced linearly with increasing level of insect meal. High inclusion levels almost always give a reduced nutrient digestibility. In line with this, both full fat and defatted black soldier fly gave lower uric acid-corrected apparent total tract CP digestibility when replacing 25\% of a basal diet containing soya bean for Ross 308 broilers [189]. Furthermore, when feeding Shaver brown broilers 30\% yellow mealworm, Bovera et al. [126] found that ileal digestibility of DM, OM, and CP was higher for birds fed diets based 
on soya bean than yellow mealworm meal. Cutrignelli et al. [151] also observed that laying hens fed $17 \%$ defatted black soldier fly had lower apparent ileal digestibility of $\mathrm{DM}, \mathrm{OM}$, and $\mathrm{CP}$ than hens fed diets containing soya bean. The nutrient composition of insects can affect protein digestibility: in an in vitro study, it was found that crude protein digestibility of black soldier fly and yellow mealworm was negatively correlated with their chitin content [121]. Removal or reduction of chitin may improve protein quality of insects. Some studies indicate that the level of sulfuric amino acids may be of importance. The inclusion of at least $20 \%$ defatted black soldier fly in broiler diets with a balanced ratio of methionine and cysteine did not give different ileal digestibilities of CP or EAA compared to a diet containing soya bean [152]. Additionally, Jensen et al. [130] found sulphuric AA to be most limiting in a rat study. Furthermore, the effect of insect meal on digestibility seems dependent on the type of insect. De Marco et al. [129] observed lower apparent ileal digestibility of the mean of AA when substituting $25 \%$ of a basal diet for broilers with full fat black soldier fly compared to yellow mealworm.

\subsubsection{Growth Performance}

Table 8 contains an overview of the effects of including insect meals on growth performance of monogastric animals. Most studies do not find any differences in growth performance parameters of pigs when supplementing up to $10 \%$ insect meal (Table 9 ). There was no effect on body weight gain or feed efficiency of weaned pigs when substituting soya bean with either 5 or $10 \%$ defatted black soldier fly [186]. Neither was there an effect on growth performance when feeding 4 or $8 \%$ full fat or $5.4 \%$ defatted black soldier fly meal to weaned pigs instead of a control diet [187]. In finishing pigs, no difference in gain or feed efficiency was observed when feeding $8 \%$ black soldier fly compared with a control diet based on soya bean and maize [191]. In the same study, feeding $4 \%$ black soldier fly increased gain and feed efficiency. A concentration of 5 or $10 \%$ yellow mealworm did give equal feed efficiency and feed intake in male grower pigs compared with feeding soya bean [190]. Daily gain, however, was reduced when feeding 10\% yellow mealworm. This coincides with a lower AA digestibility for this diet. In another study, using weaned pigs, including $2 \%$, but not 1 or $4 \%$ black soldier fly, was found to improve feed efficiency and gain compared with fishmeal [192]. None of the above-mentioned studies found a difference in feed intake.

Table 8. Summary of performance characteristics of monogastric animals fed varying inclusion levels of insect meal (Hermetia illucens, $\mathrm{HI}$ and Tenebrio molitor, TM).

\begin{tabular}{|c|c|c|c|c|c|c|}
\hline Insect & Inclusion \% & Control & Animal & Description & Effect Insect & Reference \\
\hline $\mathrm{TM}$ & $0,5,10$ & Soya bean & $\begin{array}{c}\text { Growing pig/Piétrain } \\
\times \text { German Landrace } \times \\
\text { German Edelschwein }\end{array}$ & $\begin{array}{l}\mathrm{FCR}^{1} \\
\mathrm{ADFI}^{2}\end{array}$ & $\begin{array}{l}\text { No effect } \\
\text { No effect }\end{array}$ & [190] \\
\hline $\mathrm{TM}$ & $0,5,10$ & Soya bean & Growing pig & $\mathrm{ADG}^{3}$ & Reduced at 10 & \\
\hline HI defat. & $0,5,10$ & Soya bean & $\begin{array}{l}\text { Weaned pig } \\
\text { Topigs }\end{array}$ & $\begin{array}{l}\text { ADG, } \\
\text { FCR, } \\
\text { ADFI }\end{array}$ & $\begin{array}{l}\text { No effect } \\
\text { No effect } \\
\text { No effect }\end{array}$ & [186] \\
\hline HI full/defat. & $4-8$ & Soya bean & Weaned pig & $\begin{array}{l}\text { ADG, } \\
\text { ADFI, } \\
\text { FCR }\end{array}$ & $\begin{array}{l}\text { No effect } \\
\text { No effect } \\
\text { No effect }\end{array}$ & [187] \\
\hline HI full fat & $0,4,8$ & Soya bean & $\begin{array}{l}\text { Finishing pig/Duroc } x \\
\text { Landrace } x \text { Large White }\end{array}$ & $\begin{array}{l}\text { ADG, } \\
\text { FCR }\end{array}$ & $\begin{array}{l}\text { No effect at } 8 \\
\text { Improved at } 4\end{array}$ & [191] \\
\hline HI full fat & $0,4,8$ & Soya bean & Finishing pig & ADFI & No effect & [191] \\
\hline HI full fat & $0,1,2,4$ & Fishmeal & $\begin{array}{c}\text { Weaned pig } / \text { Duroc } \times \\
\text { Landrace } \times \text { Large } \\
\text { White }\end{array}$ & $\begin{array}{l}\text { FCR, } \\
\text { ADG }\end{array}$ & $\begin{array}{l}\text { Improved at } 2 \\
\text { Increased at } 2\end{array}$ & [192] \\
\hline HI full fat & $0,1,2,4$ & Fishmeal & Weaned pig & ADFI & No effect & [192] \\
\hline
\end{tabular}


Table 8. Cont.

\begin{tabular}{|c|c|c|c|c|c|c|}
\hline Insect & Inclusion \% & Control & Animal & Description & Effect Insect & Reference \\
\hline $\mathrm{TM}$ & $0,5,10,15$ & Soya bean & Broiler/Ross 708 & ADFI & $\mathrm{L}^{4}$ increase d. $1-25$ & [127] \\
\hline $\mathrm{TM}$ & $0,5,10,15$ & Soya bean & Broiler & ADG & $\begin{array}{l}\text { L increase d. } 1-12 \\
\text { No effect d. } 12-25\end{array}$ & [127] \\
\hline $\mathrm{TM}$ & $0,5,10,15$ & Soya bean & Broiler & FCR & $\begin{array}{l}\mathrm{L} \text { increase d. } 12-25 \\
\text { No effect d. } 1-12\end{array}$ & [127] \\
\hline $\mathrm{TM}$ & $0,5,10,15$ & Soya bean & Broiler & $\begin{array}{l}\text { FCR, } \\
\text { ADFI, } \\
\text { ADG }\end{array}$ & $\begin{array}{l}\text { No effect d. } 25-40 \\
\text { No effect d. } 25-40 \\
\text { No effect d. } 25-40\end{array}$ & [127] \\
\hline $\mathrm{TM}$ & 7.5 & Gluten meal & $\begin{array}{l}\text { Broiler/Hubbard } \\
\text { hybrid JA57/S77CN } \\
\text { (slow growing) }\end{array}$ & $\begin{array}{l}\text { ADFI, } \\
\text { FCR, } \\
\text { BW }\end{array}$ & $\begin{array}{l}\text { No effect } \\
\text { No effect } \\
\text { No effect }\end{array}$ & [193] \\
\hline $\mathrm{TM}$ & 8.0 & Soya bean & Broiler/Ross 308 & $\begin{array}{l}\text { ADFI, } \\
\text { FCR }\end{array}$ & $\begin{array}{l}\text { Reduced } \\
\text { Improved }\end{array}$ & [194] \\
\hline $\mathrm{TM}$ & 8.0 & Soya bean & Broiler & ADG & Increased & [194] \\
\hline $\mathrm{TM}$ & 30 & Soya bean & Broiler/Shaver brown & FCR & Reduced & [195] \\
\hline $\mathrm{TM}$ & 30 & Soya bean & Broiler & $\begin{array}{l}\text { FCR, } \\
\text { ADFI }\end{array}$ & $\begin{array}{l}\text { No effect d. } 30-45 \\
\text { Reduced d. } 45-62\end{array}$ & [195] \\
\hline $\mathrm{TM}$ & 30 & Soya bean & Broiler & ADG & $\begin{array}{l}\text { No effect d. } 30-45 \\
\text { No effect d. } 45-62\end{array}$ & [195] \\
\hline \multirow[t]{3}{*}{ HI defat } & $0,5,10,15$ & Soya bean & Broiler/Ross 708 & $\begin{array}{l}\text { Liveweight, } \\
\text { ADG }\end{array}$ & $\begin{array}{c}L \text { and } Q^{5} \text { effect } \\
L \text { and } Q \text { effect }\end{array}$ & [196] \\
\hline & & & & ADFI & $\mathrm{L}$ and $\mathrm{Qd}$ d. $1-10$ & \\
\hline & & & & FCR & $\begin{array}{l}\text { No effect d. } 10-35 \\
\text { No effect d. } 1-10 \\
\text { L effect d. } 10-35 \\
\text { Q effect d. } 10-24\end{array}$ & \\
\hline HI defat & ca. 20 & Soya bean & Broiler/Ross 308 & FCR & $\begin{array}{l}\text { No effect d. } 1-21 \\
\text { Reduced d. } 21-35\end{array}$ & [152] \\
\hline HI defat & ca. 20 & Soya bean & Broiler & ADG & $\begin{array}{l}\text { No effect d. } 1-21 \\
\text { Reduced d. } 21-35\end{array}$ & [152] \\
\hline HI defat & ca. 20 & Soya bean & Broiler & ADFI & $\begin{array}{c}\text { Reduced d. 1-21 } \\
\text { No effect d. } 21-35\end{array}$ & [152] \\
\hline HI defat. & $0,7.8$ & $\begin{array}{l}\text { Soya bean } \\
\text { Org. }{ }^{6}\end{array}$ & $\begin{array}{l}\text { Laying hen/Hubbard } \\
\text { S757 } \\
\text { (slow growing) }\end{array}$ & ADG & No effect & [197] \\
\hline HI defat. & $0,7.3,14.6$ & Soya bean & $\begin{array}{c}\text { Laying hen/Hy-line } \\
\text { Brown }\end{array}$ & $\begin{array}{l}\text { Egg weight, } \\
\text { Bird gain, } \\
\text { FCR, } \\
\text { Laying \% }\end{array}$ & $\begin{array}{c}\text { No effect } \\
\text { No effect } \\
\text { No effect } \\
\text { Increased } 7.3\end{array}$ & [188] \\
\hline HI defat. & $0,12,24$ & $\begin{array}{l}\text { Soya bean } \\
\text { Org. }\end{array}$ & $\begin{array}{l}\text { Laying hen/Lohmann } \\
\text { Selected Leghorn }\end{array}$ & $\begin{array}{l}\text { Laying \%, } \\
\text { ADFI }\end{array}$ & $\begin{array}{l}\text { No effect } \\
\text { No effect }\end{array}$ & [146] \\
\hline HI defat. & 17 & $\begin{array}{l}\text { Soya bean } \\
\text { Org. }\end{array}$ & $\begin{array}{l}\text { Laying hen/Lohmann } \\
\text { Brown Classic }\end{array}$ & Live weight & Reduced & [151] \\
\hline \multirow[t]{2}{*}{ HI defat } & 17 & $\begin{array}{l}\text { Soya bean } \\
\text { Org. }\end{array}$ & $\begin{array}{l}\text { Laying hen/Lohmann } \\
\text { Brown Classic }\end{array}$ & $\begin{array}{l}\text { ADG, } \\
\text { ADFI, } \\
\text { FCR }\end{array}$ & $\begin{array}{l}\text { Reduced } \\
\text { Reduced } \\
\text { Reduced }\end{array}$ & [198] \\
\hline & & & & $\begin{array}{l}\text { Egg weight, } \\
\text { Laying \% }\end{array}$ & $\begin{array}{l}\text { Reduced } \\
\text { Reduced }\end{array}$ & \\
\hline
\end{tabular}

${ }^{1}$ Feed conversion ratio, i.e., $\mathrm{kg}$ feed $/ \mathrm{kg}$ gain for growing animals and $\mathrm{kg}$ feed $/ \mathrm{kg}$ egg for laying hens; ${ }^{2}$ Average daily feed intake; ${ }^{3}$ Average daily gain; ${ }^{4}$ Linear; ${ }^{5}$ Quadratic effect; ${ }^{6}$ Organic diet.

Similar to pigs, the effect of feeding insect meal on growth performance seems dosedependent in poultry. In a dose-response study, in which $0,5,10$, or $15 \%$ defatted black soldier fly was fed to broilers [196], maximum live weight and gain were observed at $10 \%$ inclusion, and a drop for both parameters was observed when exceeding this level. 
Moreover, during the last 10 growing days, gain decreased linearly with increasing levels of insect meal. FCR was affected both linearly and quadratically over the total growing period with the highest value found at $15 \%$. Conversely, when broilers were fed a diet containing around $20 \%$ defatted black soldier fly or soya bean with equal levels of methionine and cysteine, their gain and FCR were not different during the first three weeks after hatching [152]. It should be noted, however, that several EAA were supplied at higher levels in the soya bean diet of this study. Feed intake, in this study, was reduced when feeding insect meal compared to feeding a diet with soya bean. After the initial three weeks, neither gain nor feed intake was different, but FCR was reduced when feeding insect meal.

In a dose-response study, feeding $0,5,10$, or $15 \%$ yellow mealworm as a partial substitute of corn and soya bean has been found to linearly increase feed intake of broilers over the majority of their growing period [127]. Gain, however, was only linearly improved during the starter period, but not during the subsequent two weeks. This is related to the observed increase in FCR with increasing levels of yellow mealworm. In another study, feeding $7.5 \%$ yellow mealworm at the expense of gluten meal to free-range broilers did not affect any growth performance parameters [193]. In contrast, FCR and feed intake were found to be lower when feeding Shaver brown broilers $30 \%$ yellow mealworm compared with feeding soya bean in the last two weeks of the growing period [195]. Furthermore, ingested protein from yellow mealworm was found to be more efficiently utilized for growth. The authors related these results to a feed intake reduction when feeding yellow mealworm during this period. In a subsequent study, using the same diets, a reduction in ileal digestibility of crude protein was found at the end of the growing period when feeding insect meal [126]. Feed intake and body weight gain were not different during the overall growing period. On the other hand, when broilers were fed $8 \%$ yellow mealworm, an overall reduction in feed intake and an increase in gain as well as a reduction in FCR were obtained [194]. These results may have been confounded by a 39\% higher calculated methionine concentration in the insect supplemented diet. Methionine is an EAA that affects the potential for body protein deposition and subsequently determines growth.

Laying hens that ate a diet containing $17 \%$ black soldier fly had lower live weights, which could be related to lower digestibility of the insect diet [151]. In another study, it was found that neither soya bean nor 7.3 or $14.7 \%$ black soldier fly meal affected egg weight, bird gain, feed intake, or FCR (per gram of egg) of laying hens [188]. Laying percentage, however, was higher when birds were fed $7.3 \%$ black soldier fly as a partial substitute for SBM. Lohmann Brown laying hens gained and ate less when eating $17 \%$ black soldier fly than soya bean [198]. Egg weight, egg mass, and laying percentage were also lower. The FCR, however, expressed as gram of feed ingested per gram of egg, was lower. In relation to a much greater reduction in gain than the reduction in feed intake, nutrients may have been prioritized for egg formation. Feeding laying hens with either 12 or $24 \%$ black soldier fly meal instead of soya bean did not affect laying percentage, feed intake, or weights of the different components of the eggs laid [146]. Although, this may have been because the crude protein level in the high black soldier fly diet in this study was $1.4 \%$ higher than the control. Finally, when Hubbard s757 hens were fed organic diets with or without $7.8 \%$ defatted black soldier fly, growth performance did not differ [197].

\subsection{Green Protein Meal}

\subsubsection{Digestibility}

The digestibility of green protein is summarized in Table 9. Most studies are performed on rats where digestibility of protein and the biological value have been evaluated. High fecal digestibility of green protein extracted from lucerne, red clover, white clover, and perennial ryegrass was recently reported in rats $[160,163]$ with standardized $N$ digestibility of up to $88 \%$, which is similar to published values for other plant-based food products [199]. The extraction of protein from the plant fiber matrix significantly improved $\mathrm{N}$ digestibility compared to the residual pulp $[160,163]$ and for lucerne also compared to the unfractionated plant [160]. The digestibility is highly dependent on input plant material and on the process 
parameters. Szymczyk et al. [200] reported higher protein digestibility and biological value in Italian ryegrass (Lolium multiforum) (79\% and 58\%, respectively) compared to red clover (62\% and $31 \%$, respectively). Higher digestibility and biological value in grasses ( $85 \%$ and $58 \%$, respectively) compared to legumes (65\% and $45 \%$ for lucerne, $80 \%$ and $44 \%$ for red clover) was found by Maciejewicz-Rys and Hanczakowski [168] confirming differences in digestibility between species. Moreover, within a plant species, different varieties and plant development stages will influence green protein quality. This is seen in lucerne, where green protein extracted from low saponin-containing varieties had higher digestibility than green protein from high saponin lucerne [201]. During plant maturity, the content of fiber increases while the content of protein decreases [202,203]. This will affect protein extractability [159] but also gross protein value [204]. The method used for precipitation of green protein from the juice will influence digestibility [200,205-207], highlighting the importance of carefully selecting input biomass and processing method in order to maximize quality.

The ileal digestibility of amino acids was reported using green protein extracted from red clover and perennial ryegrass [208]. Standardized ileal digestibility for all indispensable amino acids ranged from 62 to $81 \%$, except for cysteine which ranged as low as $13-37 \%$, all significantly lower than of reference soya bean meal. The green protein used had crude protein contents of 33-38\% of DM [208], suggesting a high content of fiber which is known to co-precipitate with the protein [45]. A higher crude protein content of the green protein through improved harvest and processing technology may increase the nutritional quality. The improvement in digestibility is required for green biomass to be both environmentally and economically competitive as feed protein [208].

Table 9. Nutrient digestibility of diets containing protein extracted from forage crops as compared to diets containing a control ingredient when fed to monogastric animals.

\begin{tabular}{|c|c|c|c|c|c|c|}
\hline Biomass & Inclusion \% & Control & Animal & Description & Effect & Reference \\
\hline $\begin{array}{c}\text { Red clover } \\
\text { Trifolium pratense L. }\end{array}$ & 100 & Soya bean & Pig & $\begin{array}{l}\mathrm{AID}^{1} \\
\mathrm{SID}^{2}\end{array}$ & Reduced & [208] \\
\hline $\begin{array}{l}\text { Perennial Ryegrass } \\
\text { Lolium perenne }\end{array}$ & 100 & Soya bean & Pig & $\begin{array}{l}\text { AID } \\
\text { SID }\end{array}$ & Reduced & [208] \\
\hline Red clover & 100 & - & Rat & $\mathrm{TD}^{3} ; \mathrm{BV}^{4}$ & $64 ; 51$ & [206] \\
\hline Red clover & 100 & - & Rat & TD; BV & $62 ; 31$ & [200] \\
\hline $\begin{array}{l}\text { Italian ryegrass } \\
\text { Lolium multiforum }\end{array}$ & 100 & - & Rat & TD; BV & $79 ; 58$ & [200] \\
\hline Ryegrass & 100 & Lactalbumin & Rat & $\mathrm{RNV}^{5} ; \mathrm{PTD}^{6}$ & Reduced & [209] \\
\hline $\begin{array}{c}\text { Lucerne } \\
\text { Medicago sativa } L .\end{array}$ & 100 & Lactalbumin & Rat & RNV; PTD & Reduced & [209] \\
\hline $\begin{array}{l}\text { White clover } \\
\text { Trifolium repens }\end{array}$ & 100 & Lactalbumin & Rat & RNV; PTD & Reduced & [209] \\
\hline Lucerne & 100 & - & Rat & TD; BV & $86 ; 77$ & [210] \\
\hline Red clover & - & & Rat & TD; BV & $70.6 ; 53.7$ & [211] \\
\hline Lucerne & 100 & & Rat & TD; BV & $\begin{array}{l}76-88 \\
37-57\end{array}$ & [207] \\
\hline Lucerne & & & Rat & TD; BV & $65 ; 45$ & [168] \\
\hline Red clover & & & Rat & TD; BV & $80 ; 44$ & [168] \\
\hline Italian ryegrass & & & Rat & TD; BV & $85 ; 58$ & [168] \\
\hline White clover & 100 & & Rat & TD & 83.0 & [162] \\
\hline Lucerne & & & Rat & TD & 85.0 & [160] \\
\hline Red clover & & & Rat & TD & 77.4 & [160] \\
\hline Perennial Ryegrass & & & Rat & TD & 75.4 & \\
\hline White clover & & & Rat & TD & 79.3 & [160] \\
\hline
\end{tabular}

${ }^{1}$ Apparent ileal digestibility; ${ }^{2}$ Standardized ileal digestibility; ${ }^{3}$ Total tract digestibility; ${ }^{4}$ Biological value; ${ }^{5}$ Relative nutrient value; ${ }^{6}$ True protein digestibility. 


\subsubsection{Growth Performance}

Nutritional studies on green protein have mainly focused on lucerne as the raw material where the nutritive value and effect on growth of including lucerne plant juice or green protein to diets of poultry, pigs, or rats have been investigated (Table 10). The results have been inconsistent [212], likely due to improper processing and variations in the methods used [158,212].

In a feeding trial with broilers, Szymczyk et al. [200] substituted soya bean meal with green protein from red clover and reported increased average daily feed intake (ADFI) in broiler chicks in the starter period but a decreased ADFI in the finisher period. Despite an increased ADFI, the average daily gain (ADG) in the starter period was reduced, indicating a quality of green protein inferior to soya bean meal. Similarly, reduced weight gain and FCR were seen in another study where $30 \%$ and $40 \%$ of red clover green protein was included in broiler diets [213]. On the contrary, including green protein from Italian ryegrass in the diets for broilers had no effect on performance [200]. Including green protein from lucerne in broiler diets improved performance when the lucerne was a low saponin variety; however, reduced performance was seen with green protein from high saponin varieties [213]. Green protein from a mixture of grass and clover was included in the diets of the organic broilers and caused a reduced overall ADFI and slaughter weight for broilers on a diet containing $24 \%$ grass-clover protein extract. The ADG and FCR of the broilers receiving $8 \%$ grass-clover protein extract did not differ from the control during the feeding trial. The reduced performance was explained by insufficient content of EAA and a high content of protein being bound to insoluble complexes [45].

In pigs, several studies have reported inclusion of lucerne green protein without adverse effects on pig performance [205,214-217]. Hsu and Allee [217] and Sugimoto et al. [217] substituted up to $100 \%$ of the soya bean meal with green protein from lucerne, and generally the inclusion had no effect on ADG, ADFI, and FCR. However, Hsu and Allee [216] demonstrated increased weight gain in finisher pigs fed diets where 66 and $100 \%$ of the soya bean meal was substituted. Similar results were observed by Pietrzak and Grela [215] where sows in late lactation had a higher weight when lucerne (1.5-3.0\%) was included in the diets. Feeding trials with other plant species are limited and have primarily been performed with inclusions of green juice and not green protein [218-221]. The results are inconclusive, and challenges with excessive mineral levels in the juice [164] and palatability have been reported [221]. As with digestibility, process parameters will affect performance exemplified by the higher performance in pigs fed freeze-dried lucerne green protein than in pigs fed commercial lucerne protein concentrate (X-Pro) produced by drying at higher temperatures [205]. During production of the green protein, lipids in the plants are concentrated together with the extracted protein [222]. The fatty acid (FA) composition in green protein is dominated by the unsaturated omega-3 fatty acid alpha-linolenic acid, which is of nutritional importance; however, due to susceptibility to oxidative stress, the presence of unsaturated fatty acids in green protein renders the extracted protein and the final meat product more vulnerable to rancidity. Moreover, the reactive radicals produced during oxidation may pose health issues for the animals during feeding [159]. Feeding broilers with green protein produced from grass-clover resulted in an increased deposition of alpha-linolenic acid in both breast meat and fat tissue [45] and also increased the level of yellow-colorization. In an experiment with pigs, Carr and Pearson [223] reported that lucerne green protein affected some carcass parameters such as depth of eye muscles, fat, and skin. A reduced incidence of diarrhea and diarrhearelated mortality was reported when piglets were fed 1.5 and $3.0 \%$ green protein from lucerne [215]. Kwiatkowska et al. [224] demonstrated that including 1.5 and 3\% green protein from lucerne in the diet for broilers not only increased body weight at day 21 but also reduced mortality rate. Moreover, the bone mechanical strength was improved, possibly related to bioactive compounds in lucerne. The animals had increased slaughter yield, increased pectoral muscle weight, and reduced abdominal fat. 
Table 10. Summary of performance characteristics of monogastric animals fed varying inclusion levels of protein-extracted forage crops.

\begin{tabular}{|c|c|c|c|c|c|c|}
\hline Biomass & Inclusion \% & Control & Animal & Description & Effect & Reference \\
\hline $\begin{array}{c}\text { Red clover } \\
\text { Trifolium pretense L. }\end{array}$ & $\begin{array}{l}\text { 1:1 SBM protein } \\
\text { ratio }\end{array}$ & Soya bean & Broiler/Astra B & $\begin{array}{l}\mathrm{ADFI}^{1}, \\
\mathrm{ADG}^{2}\end{array}$ & $\begin{array}{l}\text { Increased w. 0-4, } \\
\text { Reduced w. 5-8 } \\
\text { Reduced w. 0-4 } \\
\text { No effect w. 5-8 }\end{array}$ & {$[200]$} \\
\hline $\begin{array}{l}\text { Italian ryegrass } \\
\text { Lolium multiforum }\end{array}$ & $\begin{array}{l}\text { 1:1 SBM protein } \\
\text { ratio }\end{array}$ & Soya bean & Broiler & $\begin{array}{l}\text { ADFI, } \\
\text { ADG }\end{array}$ & No effect & [200] \\
\hline $\begin{array}{c}\text { Lucerne/Italian } \\
\text { rye-grass/White } \\
\text { clover Trifolium } \\
\text { repens }\end{array}$ & & Casein & $\begin{array}{l}\text { Broiler Rode } \\
\text { Island Red } \times \\
\text { Light Sussex }\end{array}$ & $\begin{array}{l}\text { Weight, Gross } \\
\text { protein value }\end{array}$ & $\begin{array}{l}\text { Reduced. } \\
\text { Dependent on } \\
\text { plant maturity }\end{array}$ & [225] \\
\hline Red clover & 30,40 & & $\begin{array}{c}\text { Broiler } \\
\text { H\&N “Meat } \\
\text { Nick" }\end{array}$ & $\begin{array}{l}\text { Weight gain, } \\
\text { FCR }^{3}\end{array}$ & Reduced & [213] \\
\hline Grass-clover mix 4 & $0,8,16,24$ & $\begin{array}{l}\text { Soya press cake } \\
\text { Org. }{ }^{5}\end{array}$ & $\begin{array}{c}\text { Broiler } \\
\text { Color Yield JA57 } \\
\text { (slow growing) }\end{array}$ & $\begin{array}{l}\text { ADFI, } \\
\text { ADG, } \\
\text { FCR }\end{array}$ & $\begin{array}{c}\text { No effect at } 8 \\
\text { Reduced at } 16-24\end{array}$ & {$[45]$} \\
\hline $\begin{array}{c}\text { Lucerne } \\
\text { Medicago sativa L. }\end{array}$ & $1.5,3.0$ & Soya bean & $\begin{array}{c}\text { Broiler } \\
\text { Ross } 308\end{array}$ & $\begin{array}{l}\text { ADFI, } \\
\text { ADG, } \\
\text { FCR }\end{array}$ & $\begin{array}{c}\text { Reduced } \\
\text { Increased BW d. } \\
21 \\
\text { No effect }\end{array}$ & [224] \\
\hline $\begin{array}{c}\text { Lucerne } \\
\text { (low+high saponin; } \\
\text { LS/HS) }\end{array}$ & $10,20,30,40$ & Soya bean & $\begin{array}{l}\text { Broiler } \\
\text { Layer } \\
\text { Leghorn }\end{array}$ & $\begin{array}{l}\text { Weight gain, } \\
\text { FCR }\end{array}$ & $\begin{array}{c}\text { LS improved } \\
\text { HS: reduced } \\
\text { Reduced when } 30 \\
\text { and } 40 \% \text { wet } \\
\text { undried LS alfalfa } \\
\text { protein } \\
\text { concentrate was } \\
\text { incorporated in } \\
\text { the diets. }\end{array}$ & [213] \\
\hline Lucerne & $0,5,10,15,20$ & Soya bean & Pig & $\begin{array}{l}\text { ADG, } \\
\text { FCR }\end{array}$ & $\begin{array}{l}\text { Good } \\
\text { performance in } \\
\text { all groups }\end{array}$ & [214] \\
\hline Lucerne & - & Soya bean & $\begin{array}{l}\text { Pig } \\
\text { Yorkshire }\end{array}$ & $\begin{array}{l}\text { ADG, } \\
\text { FCR }\end{array}$ & No effect & [205] \\
\hline Lucerne & $0,33,66,100^{5}$ & Soya bean & Crossbred Pig & $\begin{array}{l}\text { ADG, } \\
\text { ADFI, } \\
\text { FCR }\end{array}$ & $\begin{array}{l}\text { Starter: no effect } \\
\text { Grower: no effect } \\
\text { Finisher: } \\
\text { increased gain at } \\
66 \text { and } 100 \%\end{array}$ & {$[216]$} \\
\hline Lucerne & $0,25,50,100^{5}$ & Soya bean & $\begin{array}{c}\text { Pig } \\
\text { Landrace }\end{array}$ & $\begin{array}{l}\text { ADG, Weight } \\
\text { gain, FCR }\end{array}$ & No effect & [217] \\
\hline Lucerne & 100 & $\begin{array}{l}\text { Fish meal+meat } \\
\text { and bone meal }\end{array}$ & $\begin{array}{c}\text { Pig } \\
\text { Landrace } \times \text { Large } \\
\text { White }\end{array}$ & $\begin{array}{l}\text { ADG, } \\
\text { ADFI }\end{array}$ & $\begin{array}{c}\text { No effect 25-80 } \\
\text { kg } \\
\text { Increased }\end{array}$ & [223] \\
\hline Lucerne & $1.5,3$ & Soya bean & $\begin{array}{c}\text { Pig (sow) } \\
\text { Polish Landrace } \\
\times \text { Polish Large } \\
\text { White }\end{array}$ & $\begin{array}{l}\text { Weight } \\
\text { growth }\end{array}$ & $\begin{array}{l}\text { Late gestation } \\
\text { sow: weight } \\
\text { increased, } \\
\text { Piglet: no effect }\end{array}$ & {$[215]$} \\
\hline Lucerne & $10,20,29,56$ & Soya bean & Rat & ADG & $\begin{array}{l}\text { No effect at } 10-20 \\
\text { Reduced at } 29-56\end{array}$ & [226] \\
\hline $\begin{array}{l}\text { Lucerne, Red clover, } \\
\text { Italian ryegrass }\end{array}$ & $100^{6}$ & $\begin{array}{c}\text { Effect of } \\
\text { precipitation } \mathrm{pH}\end{array}$ & Rat & $\begin{array}{c}\text { Intake, Growth, } \\
\text { AID }^{7}\end{array}$ & No effect & {$[227]$} \\
\hline Lucerne & 100 & Casein & Rat & Weight, PER ${ }^{8}$ & Reduced & {$[228]$} \\
\hline
\end{tabular}

${ }^{1}$ Average daily feed intake; ${ }^{2}$ Average daily gain; ${ }^{3}$ Feed conversion ratio, i.e., $\mathrm{kg}$ feed $/ \mathrm{kg}$ gain for growing animals and $\mathrm{kg}$ feed $/ \mathrm{kg}$ egg for laying hens; ${ }^{4}$ Perennial ryegrass (Lolium perenne L.), hybrid ryegrass (Lolium $x$ boucheanum), white clover (Trifolium repens L.) and red clover (Trifolium pretense L.); ${ }^{5}$ Organic diet; ${ }^{6}$ Sole protein source; ${ }^{7}$ Apparent ileal digestibility; ${ }^{8}$ Protein efficiency ratio. 


\section{Conclusions and Perspectives}

The feed ingredients reviewed in this paper, i.e., starfish, mussel, insect, and green protein extracted from perennial forages, demonstrate that there are several sustainable opportunities and challenges of increasing locally available protein for organic monogastric production in Europe. Firstly, the quality and availability of protein can be elevated via extraction of protein from forage crop proteins, which moreover stimulates transition from annual to more sustainable perennial crops. Secondly, underutilized protein, i.e., waste mussel or starfish removed to prevent mussel losses, can be used. Lastly, the development of novel and sustainable industries can provide protein, in this case insect rearing on low quality unutilized biomass. The use of mussels from eutrophication mitigation sites is, moreover, of interest as it facilitates circular use of nutrients and improves water quality. This generates feed ingredients with differing protein levels of $28-66 \%$ and similar or higher EAA:NEAA ratios to conventional ingredients. All ingredients have potential to be used for monogastrics; however, inclusion of starfish and insect is limited by calcium and chitin concentration, respectively. In particular for feeding starfish and green protein, more studies on monogastrics in organic production are needed. Future research is also needed to improve quality, environmental and economic sustainability of the processing of mussel meal and green protein. A sufficient yield can be a bottleneck for the use of starfish and green protein. Legislation may be a bottleneck for the use of insect meal in organic diets for monogastrics. If insects are to be used as a sustainable feed ingredient, more knowledge on efficiency, emissions, and energy input in relation to the type of diet that insects are reared on is needed.

Finally, it should be taken into account that single feed ingredients provide only part of the required nutrients of a complete diet, and it is necessary to have a large array of different feed ingredients to compose optimal diets for monogastric animals.

Author Contributions: Conceptualization, M.E.v.d.H. and M.S.; writing, M.E.v.d.H. and L.S.; review and editing, J.V.N., M.S., M.E.v.d.H., and L.S.; supervision, M.S. and J.V.N.; funding acquisition, M.S. All authors have read and agreed to the published version of the manuscript.

Funding: This review was written as part of the European Union's Horizon 2020 research and innovation programme under grant agreement No 773911 for the project OK-Net EcoFeed. This communication only reflects the author's view. The Research Executive Agency is not responsible for any use that may be made of the information provided.

Institutional Review Board Statement: Not applicable.

Informed Consent Statement: Not applicable.

Data Availability Statement: No new data were created or analyzed in this study. Data sharing is not applicable to this article.

Conflicts of Interest: The authors declare no conflict of interest.

\section{References}

1. EU 2018/848 regulation (EU) 2018/848 of the european parliament and of the council of 30 May 2018 on organic production and labelling of organic products and repealing Council Regulation (EC) No 834/2007. Off. J. Eur. Union 2018, L150, 1-92.

2. Eriksson, M.; Waldenstedt, L.; Engström, B.; Elwinger, K. Protein supply in organic broiler diets. Acta Agric. Scand. A Anim. Sci. 2009, 59, 211-219. [CrossRef]

3. Da Silva, V.P.; van der Werf, H.M.; Spies, A.; Soares, S.R. Variability in environmental impacts of Brazilian soybean according to crop production and transport scenarios. J. Environ. Manag. 2010, 91, 1831-1839. [CrossRef] [PubMed]

4. Früh, B.; Schlatter, B.; Isensee, A.; Maurer, V.; Willer, H. Report on Organic Protein Availability and Demand in Europe; Zumsteg Druck AG: Frick, Switzerland, 2015; pp. 1-134.

5. Deutsch, L.; Graslund, S.; Folke, C.; Troell, M.; Huitric, M.; Kautsky, N.; Lebel, L. Feeding aquaculture growth through globalization: Exploitation of marine ecosystems for fishmeal. Glob. Environ. Chang. Hum. Policy Dimens. 2007, 17, 238-249. [CrossRef]

6. Veldkamp, T.; Bosch, G. Insects: A protein-rich feed ingredient in pig and poultry diets. Anim. Front. 2015, 5, 45-50. [CrossRef]

7. Van Kernebeek, H.R.J.; Oosting, S.J.; Van Ittersum, M.K.; Bikker, P.; De Boer, I.J.M. Saving land to feed a growing population: Consequences for consumption of crop and livestock products. Int. J. Life Cycle Assess. 2015, 21, 677-687. [CrossRef] 
8. Van Raamsdonk, L.; Van der Fels-Klerx, H.; De Jong, J. New feed ingredients: The insect opportunity. Food Addit. Contam. 2017, 34, 1384-1397. [CrossRef]

9. Buschmann, A.H.; Camus, C.; Infante, J.; Neori, A.; Israel, Á.; Hernández-González, M.C.; Pereda, S.V.; Gomez-Pinchetti, J.L.; Golberg, A.; Tadmor-Shalev, N. Seaweed production: Overview of the global state of exploitation, farming and emerging research activity. Eur. J. Phyc. 2017, 52, 391-406. [CrossRef]

10. Handå, A.; Forbord, S.; Wang, X.; Broch, O.J.; Dahle, S.W.; Størseth, T.R.; Reitan, K.I.; Olsen, Y.; Skjermo, J. Seasonal-and depth-dependent growth of cultivated kelp (Saccharina latissima) in close proximity to salmon (Salmo salar) aquaculture in Norway. Aquaculture 2013, 414, 191-201. [CrossRef]

11. Moy, F.E.; Christie, H. Large-scale shift from sugar kelp (Saccharina latissima) to ephemeral algae along the south and west coast of Norway. Mar. Biol. Res. 2012, 8, 309-321. [CrossRef]

12. Manevski, K.; Lærke, P.E.; Jiao, X.; Santhome, S.; Jørgensen, U. Biomass productivity and radiation utilisation of innovative cropping systems for biorefinery. Agric. For. Meteorol. 2017, 233, 250-264. [CrossRef]

13. Manevski, K.; Lærke, P.E.; Olesen, J.E.; Jørgensen, U. Nitrogen balances of innovative cropping systems for feedstock production to future biorefineries. Sci. Total Environ. 2018, 633, 372-390. [CrossRef] [PubMed]

14. Taylor, D.; Saurel, C.; Nielsen, P.; Petersen, J.K. Production characteristics and optimization of mitigation mussel culture. Front. Mar. Sci. 2019, 6, 698. [CrossRef]

15. Petersen, J.K.; Hasler, B.; Timmermann, K.; Nielsen, P.; Tørring, D.B.; Larsen, M.M.; Holmer, M. Mussels as a tool for mitigation of nutrients in the marine environment. Mar. Pollut. Bull. 2014, 82, 137-143. [CrossRef] [PubMed]

16. Holdt, S.L.; Edwards, M.D. Cost-effective IMTA: A comparison of the production efficiencies of mussels and seaweed. J. Appl. Phycol. 2014, 26, 933-945. [CrossRef]

17. Zhang, Y.; Li, Y.; Jiang, L.; Tian, C.; Li, J.; Xiao, Z. Potential of Perennial Crop on Environmental Sustainability of Agriculture. Procedia Environ. Sci. 2011, 10, 1141-1147. [CrossRef]

18. Angus, J.; Bolger, T.; Kirkegaard, J.; Peoples, M. Nitrogen mineralisation in relation to previous crops and pastures. Soil Res. 2006, 44, 355-365. [CrossRef]

19. Espinoza, S.; Ovalle, C.; Zagal, E.; Matus, I.; Tay, J.; Peoples, M.; del Pozo, A. Contribution of legumes to wheat productivity in Mediterranean environments of central Chile. Field Crops Res. 2012, 133, 150-159. [CrossRef]

20. Oonincx, D.G.; Van Broekhoven, S.; Van Huis, A.; van Loon, J.J. Feed conversion, survival and development, and composition of four insect species on diets composed of food by-products. PLoS ONE 2015, 10, e0144601. [CrossRef]

21. Van Huis, A.; Oonincx, D.G. The environmental sustainability of insects as food and feed. A review. Agron. Sustain. Dev. 2017, 37, 43. [CrossRef]

22. EC 1069/2009 Regulation No 1069/2009 of the European Parliament and of the Council of 21 October 2009 Laying Down Health Rules as Regards Animal By-Products and Derived Products not Intended for Human Consumption and Repealing Regulation (EC) No 1774/2002 (Animal By-Products Regulation). Off. J. Eur. Union 2009, L300, 1-47.

23. Chung, I.K.; Beardall, J.; Mehta, S.; Sahoo, D.; Stojkovic, S. Using marine macroalgae for carbon sequestration: A critical appraisal. J. Appl. Phycol. 2011, 23, 877-886. [CrossRef]

24. Stagnari, F.; Maggio, A.; Galieni, A.; Pisante, M. Multiple benefits of legumes for agriculture sustainability: An overview. Chem. Biol. Technol. Agric. 2017, 4, 1-13. [CrossRef]

25. Oonincx, D.G.; De Boer, I.J. Environmental impact of the production of mealworms as a protein source for humans-a life cycle assessment. PLoS ONE 2012, 7, e51145. [CrossRef]

26. Parodi, A.; De Boer, I.J.; Gerrits, W.J.; Van Loon, J.J.; Heetkamp, M.J.; Van Schelt, J.; Bolhuis, J.E.; Van Zanten, H.H. Bioconversion efficiencies, greenhouse gas and ammonia emissions during black soldier fly rearing-A mass balance approach. J. Clean. Prod. 2020, 271, 122488. [CrossRef]

27. Petersen, J.; Gislason, H.; Fitridge, I.; Saurel, C.; Degel, H.; Nielsen, C. Fiskeri efter Søstjerner i Limfjorden; DTU Aqua: Roskilde, Denmark, 2016; pp. 1-35.

28. Puente-Rodríguez, D.; Swart, J.A.; Middag, M.; Van der Windt, H.J. Identities, communities, and practices in the transition towards Sustainable Mussel Fishery in the Dutch Wadden Sea. Hum. Ecol. 2015, 43, 93-104. [CrossRef]

29. Timmermann, K.; Maar, M.; Bolding, K.; Larsen, J.; Nielsen, P.; Petersen, J.K. Mussel production as a nutrient mitigation tool for improving marine water quality. Aquac. Envir. Inter. 2019, 11, 191-204. [CrossRef]

30. McEniry, J.; O'Kiely, P. 11-Developments in grass-/forage-based biorefineries. In Advances in Biorefineries; Waldron, K., Ed.; Woodhead Publishing: Cambridge, UK, 2014; pp. 335-363.

31. Njakou Djomo, S.; Knudsen, M.T.; Martinsen, L.; Andersen, M.S.; Ambye-Jensen, M.; Møller, H.B.; Hermansen, J.E. Green proteins: An energy-efficient solution for increased self-sufficiency in protein in Europe. Biofuels Bioprod. Bioref. 2020, 14, 605-619. [CrossRef]

32. Verbeke, W. Profiling consumers who are ready to adopt insects as a meat substitute in a Western society. Food Qual. Prefer. 2015, 39, 147-155. [CrossRef]

33. Fernández, A.; Grienke, U.; Soler-Vila, A.; Guihéneuf, F.; Stengel, D.B.; Tasdemir, D. Seasonal and geographical variations in the biochemical composition of the blue mussel (Mytilus edulis L.) from Ireland. Food Chem. 2015, 177, 43-52. [CrossRef] [PubMed]

34. Gupta, S.; Cox, S.; Abu-Ghannam, N. Effect of different drying temperatures on the moisture and phytochemical constituents of edible Irish brown seaweed. LWT Food Sci. Technol. 2011, 44, 1266-1272. [CrossRef] 
35. Sharma, H.S.; Lyons, G.; McRoberts, C. Biorefining of perennial grasses: A potential sustainable option for Northern Ireland grassland production. Chem. Eng. Res. Des. 2011, 89, 2309-2321. [CrossRef]

36. Nielsen, M.M.; Manns, D.; D’Este, M.; Krause-Jensen, D.; Rasmussen, M.B.; Larsen, M.M.; Alvarado-Morales, M.; Angelidaki, I.; Bruhn, A. Variation in biochemical composition of Saccharina latissima and Laminaria digitata along an estuarine salinity gradient in inner Danish waters. Algal Res. 2016, 13, 235-245. [CrossRef]

37. Wang, J.; Zhang, M.; Fang, Z. Recent development in efficient processing technology for edible algae: A review. Trends Food Sci. Technol. 2019, 88, 251-259. [CrossRef]

38. Berge, G.M.; Austreng, E. Blue mussel in feed for rainbow trout. Aquaculture 1989, 81, 79-90. [CrossRef]

39. Veldkamp, T.; Van Niekerk, T. Live black soldier fly larvae (Hermetia illucens) for turkey poults. J. Insects Food Feed 2019, 5, 301-311. [CrossRef]

40. Woods, M.; Cullere, M.; Van Emmenes, L.; Vincenzi, S.; Pieterse, E.; Hoffman, L.; Zotte, A.D. Hermetia illucens larvae reared on different substrates in broiler quail diets: Effect on apparent digestibility, feed-choice and growth performance. J. Insects Food Feed 2019, 5, 89-98. [CrossRef]

41. Larsen, S.U.; Jørgensen, H.; Bukh, C.; Schjoerring, J.K. Green biorefining: Effect of nitrogen fertilization on protein yield, protein extractability and amino acid composition of tall fescue biomass. Ind. Crops Prod. 2019, 130, 642-652. [CrossRef]

42. Colas, D.; Doumeng, C.; Pontalier, P.Y.; Rigal, L. Green crop fractionation by twin-screw extrusion: Influence of the screw profile on alfalfa (Medicago sativa) dehydration and protein extraction. Chem. Eng. Process. 2013, 72, 1-9. [CrossRef]

43. Santamaria-Fernandez, M.; Ambye-Jensen, M.; Damborg, V.K.; Lübeck, M. Demonstration-scale protein recovery by lactic acid fermentation from grass clover-A single case of the production of protein concentrate and press cake silage for animal feeding trials. Biofuels Bioprod. Bioref. 2018, 13, 502-513. [CrossRef]

44. Damborg, V.K.; Jensen, S.K.; Weisbjerg, M.R.; Adamsen, A.P.; Stødkilde, L. Screw-pressed fractions from green forages as animal feed: Chemical composition and mass balances. Anim. Feed Sci. Technol. 2020, 261, 114401. [CrossRef]

45. Stødkilde, L.; Ambye-Jensen, M.; Jensen, S.K. Biorefined grass-clover protein composition and effect on organic broiler performance and meat fatty acid profile. J. Anim. Physiol. Anim. Nutr. 2020, 104, 1757-1767. [CrossRef]

46. Santamaría-Fernández, M.; Lübeck, M. Production of leaf protein concentrates in green biorefineries as alternative feed for monogastric animals. Anim. Feed Sci. Technol. 2020, 268, 114605. [CrossRef]

47. De Jong, E.; Jungmeier, G. Biorefinery concepts in comparison to petrochemical refineries. In Industrial Biorefineries $\mathcal{E}$ White Biotechnology, 1st ed.; Pandey, A., Höfer, R., Taherzadeh, M., Nampoothiri, K.M., Larroche, C., Eds.; Elsevier: Amsterdam, The Netherlands, 2015; pp. 3-33.

48. Dale, B.E.; Allen, M.S.; Laser, M.; Lynd, L.R. Protein feeds coproduction in biomass conversion to fuels and chemicals. Biofuels Bioprod. Bioref. 2009, 3, 219-230. [CrossRef]

49. Kragbæk Damborg, V.; Krogh Jensen, S.; Johansen, M.; Ambye-Jensen, M.; Weisbjerg, M.R. Ensiled pulp from biorefining increased milk production in dairy cows compared with grass-clover silage. J. Dairy Sci. 2019, 102, 8883-8897. [CrossRef]

50. Santamaría-Fernández, M.; Molinuevo-Salces, B.; Lübeck, M.; Uellendahl, H. Biogas potential of green biomass after protein extraction in an organic biorefinery concept for feed, fuel and fertilizer production. Renew. Energy 2018, 129, 769-775. [CrossRef]

51. Keto, L.; Perttilä; Särkijärvi, S.; Kamppari, K.; Immonen, I.; Kytölä, K.; Ertbjerg, P.; Rinne, M. Grass Silage for Biorefinery—Silage Juice as a Dietary Component for Growing Pigs; European Grassland Federation: Helsinki, Finland, 2020.

52. Audren, G.; Classen, H.; Schwean, K.; Racz, V. Nutritional value of wheat screenings for broiler chickens. Can. J. Anim. Sci. 2002, 82, 393-398. [CrossRef]

53. Steenfeldt, S. The dietary effect of different wheat cultivars for broiler chickens. Br. Poult. Sci. 2001, 42, 595-609. [CrossRef]

54. Zijlstra, R.; Lange, C.D.; Patience, J. Nutritional value of wheat for growing pigs: Chemical composition and digestible energy content. Can. J. Anim. Sci. 1999, 79, 187-194. [CrossRef]

55. Barzegar, S.; Wu, S.-B.; Noblet, J.; Swick, R.A. Metabolizable energy of corn, soybean meal and wheat for laying hens. Poult. Sci. 2019, 98, 5876-5882. [CrossRef]

56. Feed Tables Wheat Feed Flour. Available online: https:/ /www.feedtables.com/content/wheat-feed-flour (accessed on 26 August 2020).

57. Feed Tables Wheat Soft. Available online: https:/ /www.feedtables.com/content/wheat-soft (accessed on 26 August 2020).

58. Ao, X.; Kim, I. Effects of dietary dried mealworm (Ptecticus tenebrifer) larvae on growth performance and nutrient digestibility in weaning pigs. Livestock Sci. 2019, 230, 103815. [CrossRef]

59. Lagos, L.V.; Stein, H.H. Torula yeast has greater digestibility of amino acids and phosphorus, but not energy, compared with a commercial source of fish meal fed to weanling pigs. J. Anim. Sci. 2020, 98, skz375. [CrossRef] [PubMed]

60. Li, R.; Hou, G.; Song, Z.; Zhao, J.; Fan, Z.; Hou, D.; He, X. Nutritional value of enzyme-treated soybean meal, concentrated degossypolized cottonseed protein, dried porcine solubles and fish meal for 10-to-20 kg pigs. Anim. Feed Sci. Technol. 2019, 252, 23-33. [CrossRef]

61. Oliveira, M.; Espinosa, C.; Berrocoso, J.; Rojas, O.; Htoo, J.; Stein, H. Concentration of digestible and metabolizable energy in L-threonine and L-valine biomass products fed to weanling pigs. Anim. Feed Sci. Technol. 2020, 263, 114463. [CrossRef]

62. Sinn, S.; Gibbons, W.; Brown, M.; DeRouchey, J.; Levesque, C. Evaluation of microbially enhanced soybean meal as an alternative to fishmeal in weaned pig diets. Animal 2017, 11, 784-793. [CrossRef] [PubMed] 
63. Sørensen, P.; Nørgaard, J.V. Starfish (Asterias rubens) as feed ingredient for piglets. Anim. Feed Sci. Technol. 2016, 211, 181-188. [CrossRef]

64. Trosvik, K.A.; Rawles, S.D.; Thompson, K.R.; Metts, L.A.; Gannam, A.; Twibell, R.; Webster, C.D. Growth and body composition of Nile tilapia, Oreochromis niloticus, fry fed organic diets containing yeast extract and soybean meal as replacements for fish meal, with and without supplemental lysine and methionine. J. World Aquacult. Soc. 2012, 43, 635-647. [CrossRef]

65. Hammershøj, M.; Steenfeldt, S. Effects of blue lupin (Lupinus angustifolius) in organic layer diets and supplementation with foraging material on egg production and some egg quality parameters. Poult. Sci. 2005, 84, 723-733. [CrossRef]

66. Jacob, J. Nutrient content of organically grown feedstuffs. J. Appl. Poult. Res. 2007, 16, 642-651. [CrossRef]

67. Feed Tables Soybean Meal, Oil 5-20\%. Available online: https://www.feedtables.com/content/soybean-meal-oil-5-20 (accessed on 13 October 2020).

68. National Research Council, Nutrient Requirements of Swine; National Academies Press: Washington, DC, USA, 2012.

69. Grkovic, N.; Dimitrijevic, M.; Teodorovic, V.; Karabasil, N.; Vasilev, D.; Stajkovic, S.; Velebit, B. Factors Influencing Mussel (Mytilus Galloprovincialis) Nutritional Quality; IOP Conference Series: Earth and Environmental Science, 2019; IOP Publishing: Bristol, UK, 2019; pp. 1-6.

70. Lemaire, N.; Pellerin, J.; Fournier, M.; Girault, L.; Tamigneaux, E.; Cartier, S.; Pelletier, E. Seasonal variations of physiological parameters in the blue mussel Mytilus spp. from farm sites of eastern Quebec. Aquaculture 2006, 261, 729-751. [CrossRef]

71. Ferguson, J.C. The role of free amino acids in nitrogen storage during the annual cycle of a starfish. Comp. Biochem. Phys. A Phys. 1975, 51, 341-350. [CrossRef]

72. Rubilar, T.; de Vivar, M.D.; de Ward, C.P. Biochemical composition of body compartments during the reproductive cycle of the starfish Allostichaster capensis in Patagonia, Argentina. Rev. Biol. Trop. 2008, 56, 351-360. [CrossRef]

73. Van der Heide, M.E.; Møller, L.F.; Petersen, J.K.; Nørgaard, J.V. Annual variation in the composition of major nutrients of the common starfish (Asterias rubens). Anim. Feed Sci. Technol. 2018, 238, 91-97. [CrossRef]

74. Nørgaard, J.V.; Petersen, J.K.; Tørring, D.B.; Jørgensen, H.; Lærke, H. Chemical composition and standardized ileal digestibility of protein and amino acids from blue mussel, starfish, and fish silage in pigs. Anim. Feed Sci. Technol. 2015, 205, 90-97. [CrossRef]

75. Jönsson, L.; Elwinger, K. Mussel meal as a replacement for fish meal in feeds for organic poultry-A pilot short-term study. Acta Agric. Scand. A Anim. Sci. 2009, 59, 22-27. [CrossRef]

76. Nagel, F.; von Danwitz, A.; Schlachter, M.; Kroeckel, S.; Wagner, C.; Schulz, C. Blue mussel meal as feed attractant in rapeseed protein-based diets for turbot (Psetta maxima L.). Aquacult. Res. 2014, 45, 1964-1978. [CrossRef]

77. Langeland, M.; Vidakovic, A.; Vielma, J.; Lindberg, J.; Kiessling, A.; Lundh, T. Digestibility of microbial and mussel meal for Arctic charr (Salvelinus alpinus) and Eurasian perch (Perca fluviatilis). Aquacult. Nutr. 2016, 22, 485-495. [CrossRef]

78. Van der Heide, M.E.; Carlson, D.; Nørgaard, J.V. Growth performance of weaned pigs fed different levels of starfish meal. Anim. Feed Sci. Technol. 2018, 238, 84-90. [CrossRef]

79. Stiger-Pouvreau, V.; Bourgougnon, N.; Deslandes, E. Carbohydrates from seaweeds. In Seaweed in Health and Disease Prevention; Fluerence, J., Levine, I., Eds.; Elsevier: London, UK, 2016; pp. 223-274.

80. Øverland, M.; Mydland, L.T.; Skrede, A. Marine macroalgae as sources of protein and bioactive compounds in feed for monogastric animals. J. Sci. Food Agric. 2019, 99, 13-24. [CrossRef]

81. Bikker, P.; Stokvis, L.; van Krimpen, M.; van Wikselaar, P.; Cone, J. Evaluation of seaweeds from marine waters in Northwestern Europe for application in animal nutrition. Anim. Feed Sci. Technol. 2020, 263, 114460. [CrossRef]

82. Moen, E.; Horn, S.; Østgaard, K. Biological degradation of Ascophyllum nodosum. J. Appl. Phycol. 1997, 9, 347-357. [CrossRef]

83. Gardiner, G.E.; Campbell, A.J.; O’Doherty, J.V.; Pierce, E.; Lynch, P.B.; Leonard, F.C.; Stanton, C.; Ross, R.P.; Lawlor, P.G. Effect of Ascophyllum nodosum extract on growth performance, digestibility, carcass characteristics and selected intestinal microflora populations of grower-finisher pigs. Anim. Feed Sci. Technol. 2008, 141, 259-273. [CrossRef]

84. Tibbetts, S.M.; Milley, J.E.; Lall, S.P. Nutritional quality of some wild and cultivated seaweeds: Nutrient composition, total phenolic content and in vitro digestibility. J. Appl. Phycol. 2016, 28, 3575-3585. [CrossRef]

85. Creech, B.; Spears, J.; Flowers, W.; Hill, G.; Lloyd, K.; Armstrong, T.; Engle, T. Effect of dietary trace mineral concentration and source (inorganic vs. chelated) on performance, mineral status, and fecal mineral excretion in pigs from weaning through finishing. J. Anim. Sci. 2004, 82, 2140-2147. [CrossRef] [PubMed]

86. Lei, X.J.; Chung, J.Y.; Park, J.H.; Kim, I.H. Evaluation of different dietary electrolyte balance in weanling pigs diets. Anim. Feed Sci. Technol. 2017, 226, 98-102. [CrossRef]

87. Sharma, S.; Neves, L.; Funderud, J.; Mydland, L.T.; Øverland, M.; Horn, S.J. Seasonal and depth variations in the chemical composition of cultivated Saccharina latissima. Algal Res. 2018, 32, 107-112. [CrossRef]

88. Ometto, F.; Steinhovden, K.B.; Kuci, H.; Lunnbäck, J.; Berg, A.; Karlsson, A.; Handå, A.; Wollan, H.; Ejlertsson, J. Seasonal variation of elements composition and biomethane in brown macroalgae. Biomass Bioenerg. 2018, 109, 31-38. [CrossRef]

89. Ventura, M.; Castañón, J. The nutritive value of seaweed (Ulva lactuca) for goats. Small Ruminant Res. 1998, 29, 325-327. [CrossRef]

90. Tabarsa, M.; Rezaei, M.; Ramezanpour, Z.; Waaland, J.R. Chemical compositions of the marine algae Gracilaria salicornia (Rhodophyta) and Ulva lactuca (Chlorophyta) as a potential food source. J. Sci. Food Agric. 2012, 92, 2500-2506. [CrossRef]

91. Arieli, A.; Sklan, D.; Kissil, G. A note on the nutritive value of Ulva lactuca for ruminants. Anim. Sci. 1993, 57, 329-331. [CrossRef]

92. Gaillard, C.; Bhatti, H.S.; Novoa-Garrido, M.; Lind, V.; Roleda, M.Y.; Weisbjerg, M.R. Amino acid profiles of nine seaweed species and their in situ degradability in dairy cows. Anim. Feed Sci. Technol. 2018, 241, 210-222. [CrossRef] 
93. Ortiz, J.; Romero, N.; Robert, P.; Araya, J.; Lopez-Hernandez, J.; Bozzo, C.; Navarrete, E.; Osorio, A.; Rios, A. Dietary fiber, amino acid, fatty acid and tocopherol contents of the edible seaweeds Ulva lactuca and Durvillaea antarctica. Food Chem. 2006, 99, 98-104. [CrossRef]

94. Abudabos, A.M.; Okab, A.B.; Aljumaah, R.S.; Samara, E.M.; Abdoun, K.A.; Al-Haidary, A.A. Nutritional value of green seaweed (Ulva lactuca) for broiler chickens. Ital. J. Anim. Sci. 2013, 12, 177-181. [CrossRef]

95. Pádua, M.D.; Fontoura, P.S.G.; Mathias, A.L. Chemical composition of Ulvaria oxysperma (Kützing) bliding, Ulva lactuca (Linnaeus) and Ulva fascita (Delile). Braz. Arch. Biol. Technol. 2004, 47, 49-55. [CrossRef]

96. Khairy, H.M.; El-Shafay, S.M. Seasonal variations in the biochemical composition of some common seaweed species from the coast of Abu Qir Bay, Alexandria, Egypt. Oceanologia 2013, 55, 435-452. [CrossRef]

97. Okab, A.B.; Samara, E.M.; Abdoun, K.A.; Rafay, J.; Ondruska, L.; Parkanyi, V.; Pivko, J.; Ayoub, M.A.; Al-Haidary, A.A.; Aljumaah, R.S. Effects of dietary seaweed (Ulva lactuca) supplementation on the reproductive performance of buck and doe rabbits. J. Appl. Anim. Res. 2013, 41, 347-355. [CrossRef]

98. Ho, Y. Mineral element content in Ulva lactuca L. with reference to eutrophication in Hong Kong coastal waters. Hydrobiologia 1981, 77, 43-47. [CrossRef]

99. Rohani-Ghadikolaei, K.; Abdulalian, E.; Ng, W.-K. Evaluation of the proximate, fatty acid and mineral composition of representative green, brown and red seaweeds from the Persian Gulf of Iran as potential food and feed resources. J. Food Sci. Technol. 2012, 49, 774-780. [CrossRef]

100. Yoganandham, S.T.; Raguraman, V.; Muniswamy, G.; Sathyamoorthy, G.; Renuka, R.R.; Chidambaram, J.; Rajendran, T.; Chandrasekaran, K.; Ravindranath, R.R.S. Mineral and trace metal concentrations in seaweeds by microwave-assisted digestion method followed by quadrupole inductively coupled plasma mass spectrometry. Biol. Trace Elem. Res. 2019, 187, 579-585. [CrossRef]

101. Oucif, H.; Benaissa, M.; Ali Mehidi, S.; Prego, R.; Aubourg, S.P.; Abi-Ayad, S.-M. Chemical Composition and Nutritional Value of Different Seaweeds from the West Algerian Coast. J. Aquat. Food Prod. Technol. 2020, 29, 90-104. [CrossRef]

102. Maia, M.R.; Fonseca, A.J.; Oliveira, H.M.; Mendonça, C.; Cabrita, A.R. The potential role of seaweeds in the natural manipulation of rumen fermentation and methane production. Sci. Rep. 2016, 6, 32321. [CrossRef] [PubMed]

103. Cabrita, A.R.; Maia, M.R.; Oliveira, H.M.; Sousa-Pinto, I.; Almeida, A.A.; Pinto, E.; Fonseca, A.J. Tracing seaweeds as mineral sources for farm-animals. J. Appl. Phycol. 2016, 28, 3135-3150. [CrossRef]

104. Yaich, H.; Garna, H.; Besbes, S.; Paquot, M.; Blecker, C.; Attia, H. Chemical composition and functional properties of Ulva lactuca seaweed collected in Tunisia. Food Chem. 2011, 128, 895-901. [CrossRef]

105. Zhu, D.; Wen, X.; Xuan, X.; Li, S.; Li, Y. The green alga Ulva lactuca as a potential ingredient in diets for juvenile white spotted snapper Lutjanus stellatus Akazaki. J. Appl. Phycol. 2016, 28, 703-711. [CrossRef]

106. Afonso, C.; Cardoso, C.; Ripol, A.; Varela, J.; Quental-Ferreira, H.; Pousão-Ferreira, P.; Ventura, M.; Delgado, I.; Coelho, I.; Castanheira, I. Composition and bioaccessibility of elements in green seaweeds from fish pond aquaculture. Food Res. Int. 2018, 105, 271-277. [CrossRef] [PubMed]

107. Nielsen, M.M.; Bruhn, A.; Rasmussen, M.B.; Olesen, B.; Larsen, M.M.; Møller, H.B. Cultivation of Ulva lactuca with manure for simultaneous bioremediation and biomass production. J. Appl. Phycol. 2012, 24, 449-458. [CrossRef]

108. Shuuluka, D.; Bolton, J.J.; Anderson, R.J. Protein content, amino acid composition and nitrogen-to-protein conversion factors of Ulva rigida and Ulva capensis from natural populations and Ulva lactuca from an aquaculture system, in South Africa. J. Appl. Phycol. 2013, 25, 677-685. [CrossRef]

109. Cruz-Suárez, L.E.; Tapia-Salazar, M.; Nieto-López, M.; Guajardo-Barbosa, C.; Ricque-Marie, D. Comparison of Ulva clathrata and the kelps Macrocystis pyrifera and Ascophyllum nodosum as ingredients in shrimp feeds. Aquacult. Nutr. 2009, 15, 421-430. [CrossRef]

110. Erickson, P.S.; Marston, S.; Gemmel, M.; Deming, J.; Cabral, R.; Murphy, M.; Marden, J. Kelp taste preferences by dairy calves. J. Dairy Sci. 2012, 95, 856-858. [CrossRef]

111. Dierick, N.; Ovyn, A.; De Smet, S. Effect of feeding intact brown seaweed Ascophyllum nodosum on some digestive parameters and on iodine content in edible tissues in pigs. J. Sci. Food Agric. 2009, 89, 584-594. [CrossRef]

112. Tabassum, M.R.; Xia, A.; Murphy, J.D. Seasonal variation of chemical composition and biomethane production from the brown seaweed Ascophyllum nodosum. Biores. Technol. 2016, 216, 219-226. [CrossRef]

113. Rioux, L.-E.; Beaulieu, L.; Turgeon, S.L. Seaweeds: A traditional ingredients for new gastronomic sensation. Food Hydrocoll. 2017, 68, 255-265. [CrossRef]

114. Peinado, I.; Girón, J.; Koutsidis, G.; Ames, J. Chemical composition, antioxidant activity and sensory evaluation of five different species of brown edible seaweeds. Food Res. Int. 2014, 66, 36-44. [CrossRef]

115. Lorenzo, J.M.; Agregán, R.; Munekata, P.E.; Franco, D.; Carballo, J.; Şahin, S.; Lacomba, R.; Barba, F.J. Proximate composition and nutritional value of three macroalgae: Ascophyllum nodosum, Fucus vesiculosus and Bifurcaria bifurcata. Mar. Drugs 2017, 15, 360. [CrossRef] [PubMed]

116. Villares, R.; Fernández-Lema, E.; López-Mosquera, E. Seasonal variations in concentrations of macro-and micronutrients in three species of brown seaweed. Bot. Mar. 2013, 56, 49-61. [CrossRef] 
117. Vieira, E.F.; Soares, C.; Machado, S.; Correia, M.; Ramalhosa, M.J.; Oliva-Teles, M.T.; Carvalho, A.P.; Domingues, V.F.; Antunes, F.; Oliveira, T.A.C. Seaweeds from the Portuguese coast as a source of proteinaceous material: Total and free amino acid composition profile. Food Chem. 2018, 269, 264-275. [CrossRef] [PubMed]

118. Stévant, P.; Marfaing, H.; Rustad, T.; Sandbakken, I.; Fleurence, J.; Chapman, A. Nutritional value of the kelps Alaria esculenta and Saccharina latissima and effects of short-term storage on biomass quality. J. Appl. Phycol. 2017, 29, 2417-2426. [CrossRef]

119. Schiener, P.; Black, K.D.; Stanley, M.S.; Green, D.H. The seasonal variation in the chemical composition of the kelp species Laminaria digitata, Laminaria hyperborea, Saccharina latissima and Alaria esculenta. J. Appl. Phycol. 2015, 27, 363-373. [CrossRef]

120. Finke, M.D. Estimate of chitin in raw whole insects. Zoo Biol. 2007, 26, 105-115. [CrossRef] [PubMed]

121. Marono, S.; Piccolo, G.; Loponte, R.; Di Meo, C.; Attia, Y.A.; Nizza, A.; Bovera, F. In vitro crude protein digestibility of Tenebrio molitor and Hermetia illucens insect meals and its correlation with chemical composition traits. Ital. J. Anim. Sci. 2015, 14, 338-342. [CrossRef]

122. Ruhnke, I.; Normant, C.; Campbell, D.L.; Iqbal, Z.; Lee, C.; Hinch, G.N.; Roberts, J. Impact of on-range choice feeding with black soldier fly larvae (Hermetia illucens) on flock performance, egg quality, and range use of free-range laying hens. Anim. Nutr. 2018, 4, 452-460. [CrossRef] [PubMed]

123. Tybirk, P.; Sloth, N.; Jørgensen, L. Nutrient Recommendations; SEGES the Danish Research Center: Copenhagen, Denmark, 2018.

124. Rodenburg, T.; Van Harn, J.; Van Krimpen, M.; Ruis, M.; Vermeij, I.; Spoolder, H. Comparison of three different diets for organic broilers: Effects on performance and body condition. Br. Poult. Sci. 2008, 49, 74-80. [CrossRef]

125. Meneguz, M.; Schiavone, A.; Gai, F.; Dama, A.; Lussiana, C.; Renna, M.; Gasco, L. Effect of rearing substrate on growth performance, waste reduction efficiency and chemical composition of black soldier fly (Hermetia illucens) larvae. J. Sci. Food Agric. 2018, 98, 5776-5784. [CrossRef]

126. Bovera, F.; Loponte, R.; Marono, S.; Piccolo, G.; Parisi, G.; Iaconisi, V.; Gasco, L.; Nizza, A. Use of Tenebrio molitor larvae meal as protein source in broiler diet: Effect on growth performance, nutrient digestibility, and carcass and meat traits. J. Anim. Sci. 2016, 94, 639-647. [CrossRef]

127. Biasato, I.; Gasco, L.; De Marco, M.; Renna, M.; Rotolo, L.; Dabbou, S.; Capucchio, M.; Biasibetti, E.; Tarantola, M.; Bianchi, C. Effects of yellow mealworm larvae (Tenebrio molitor) inclusion in diets for female broiler chickens: Implications for animal health and gut histology. Anim. Feed Sci. Technol. 2017, 234, 253-263. [CrossRef]

128. Józefiak, A.; Kierończyk, B.; Rawski, M.; Mazurkiewicz, J.; Benzertiha, A.; Gobbi, P.; Nogales-Merida, S.; Świątkiewicz, S.; Józefiak, D. Full-fat insect meals as feed additive-the effect on broiler chicken growth performance and gastrointestinal tract microbiota. J. Anim. Feed Sci. 2018, 27, 131-139. [CrossRef]

129. De Marco, M.; Martinez, S.; Hernandez, F.; Madrid, J.; Gai, F.; Rotolo, L.; Belforti, M.; Bergero, D.; Katz, H.; Dabbou, S.; et al. Nutritional value of two insect larval meals (Tenebrio molitor and Hermetia illucens) for broiler chickens: Apparent nutrient digestibility, apparent ileal amino acid digestibility and apparent metabolizable energy. Anim. Feed Sci. Technol. 2015, 209, 211-218. [CrossRef]

130. Jensen, L.; Miklos, R.; Dalsgaard, T.; Heckmann, L.; Nørgaard, J. Nutritional evaluation of common (Tenebrio molitor) and lesser (Alphitobius diaperinus) mealworms in rats and processing effect on the lesser mealworm. J. Insects Food Feed 2019, 5, 1-10. [CrossRef]

131. Kowalska, D.; Gugołek, A.; Strychalski, J. Evaluation of slaughter parameters and meat quality of rabbits fed diets with silkworm pupae and mealworm larvae meals. Ann. Anim. Sci. 2019, 20, 551-564. [CrossRef]

132. Gasco, L.; Henry, M.; Piccolo, G.; Marono, S.; Gai, F.; Renna, M.; Lussiana, C.; Antonopoulou, E.; Mola, P.; Chatzifotis, S. Tenebrio molitor meal in diets for European sea bass (Dicentrarchus labrax L.) juveniles: Growth performance, whole body composition and in vivo apparent digestibility. Anim. Feed Sci. Technol. 2016, 220, 34-45. [CrossRef]

133. Siemianowska, E.; Kosewska, A.; Aljewicz, M.; Skibniewska, K.A.; Polak-Juszczak, L.; Jarocki, A.; Jedras, M. Larvae of mealworm (Tenebrio molitor L.) as European novel food. Agricult. Sci. 2013, 04, 287-291. [CrossRef]

134. Biasato, I.; Ferrocino, I.; Grego, E.; Dabbou, S.; Gai, F.; Gasco, L.; Cocolin, L.; Capucchio, M.T.; Schiavone, A. Gut microbiota and mucin composition in female broiler chickens fed diets including yellow mealworm (Tenebrio molitor L.). Animals 2019 , 9, 213. [CrossRef]

135. Sankian, Z.; Khosravi, S.; Kim, Y.-O.; Lee, S.-M. Effects of dietary inclusion of yellow mealworm (Tenebrio molitor) meal on growth performance, feed utilization, body composition, plasma biochemical indices, selected immune parameters and antioxidant enzyme activities of mandarin fish (Siniperca scherzeri) juveniles. Aquaculture 2018, 496, 79-87. [CrossRef]

136. Wu, R.A.; Ding, Q.; Yin, L.; Chi, X.; Sun, N.; He, R.; Luo, L.; Ma, H.; Li, Z. Comparison of the nutritional value of mysore thorn borer (Anoplophora chinensis) and mealworm larva (Tenebrio molitor): Amino acid, fatty acid, and element profiles. Food Chem. 2020, 323, 126818. [CrossRef]

137. Basto, A.; Matos, E.; Valente, L.M. Nutritional value of different insect larvae meals as protein sources for European sea bass (Dicentrarchus labrax) juveniles. Aquaculture 2020, 521, 735085. [CrossRef]

138. Mastoraki, M.; Ferrándiz, P.M.; Vardali, S.C.; Kontodimas, D.C.; Kotzamanis, Y.P.; Gasco, L.; Chatzifotis, S.; Antonopoulou, E. A comparative study on the effect of fish meal substitution with three different insect meals on growth, body composition and metabolism of European sea bass (Dicentrarchus labrax L.). Aquaculture 2020, 528, 735511. [CrossRef] 
139. Van Broekhoven, S.; Oonincx, D.G.; Van Huis, A.; Van Loon, J.J. Growth performance and feed conversion efficiency of three edible mealworm species (Coleoptera: Tenebrionidae) on diets composed of organic by-products. J. Insect Physiol. 2015, 73, 1-10. [CrossRef] [PubMed]

140. Yi, L.; Lakemond, C.M.; Sagis, L.M.; Eisner-Schadler, V.; van Huis, A.; van Boekel, M.A. Extraction and characterisation of protein fractions from five insect species. Food Chem. 2013, 141, 3341-3348. [CrossRef]

141. Bosch, G.; Zhang, S.; Oonincx, D.G.; Hendriks, W.H. Protein quality of insects as potential ingredients for dog and cat foods. J. Nutr. Sci. 2014, 3, 1-4. [CrossRef]

142. Janssen, R.H.; Vincken, J.-P.; van den Broek, L.A.; Fogliano, V.; Lakemond, C.M. Nitrogen-to-protein conversion factors for three edible insects: Tenebrio molitor, Alphitobius diaperinus, and Hermetia illucens. J. Agric. Food Chem. 2017, 65, 2275-2278. [CrossRef]

143. Despins, J.; Axtell, R. Feeding behavior and growth of turkey poults fed larvae of the darkling beetle, Alphitobius diaperinus. Poult. Sci. 1994, 73, 1526-1533. [CrossRef]

144. Roncolini, A.; Milanović, V.; Aquilanti, L.; Cardinali, F.; Garofalo, C.; Sabbatini, R.; Clementi, F.; Belleggia, L.; Pasquini, M.; Mozzon, M. Lesser mealworm (Alphitobius diaperinus) powder as a novel baking ingredient for manufacturing high-protein, mineral-dense snacks. Food Res. Int. 2020, 131, 109031. [CrossRef]

145. Leni, G.; Soetemans, L.; Jacobs, J.; Depraetere, S.; Gianotten, N.; Bastiaens, L.; Caligiani, A.; Sforza, S. Protein hydrolysates from Alphitobius diaperinus and Hermetia illucens larvae treated with commercial proteases. J. Insects Food Feed 2020, 6, 393-404. [CrossRef]

146. Maurer, V.; Holinger, M.; Amsler, Z.; Früh, B.; Wohlfahrt, J.; Stamer, A.; Leiber, F. Replacement of soybean cake by Hermetia illucens meal in diets for layers. J. Insects Food Feed 2016, 2, 83-90. [CrossRef]

147. Liland, N.S.; Biancarosa, I.; Araujo, P.; Biemans, D.; Bruckner, C.G.; Waagbø, R.; Torstensen, B.E.; Lock, E.-J. Modulation of nutrient composition of black soldier fly (Hermetia illucens) larvae by feeding seaweed-enriched media. PLoS ONE 2017, 12, e0183188. [CrossRef] [PubMed]

148. Zhen, Y.; Chundang, P.; Zhang, Y.; Wang, M.; Vongsangnak, W.; Pruksakorn, C.; Kovitvadhi, A. Impacts of Killing Process on the Nutrient Content, Product Stability and In Vitro Digestibility of Black Soldier Fly (Hermetia illucens) Larvae Meals. Appl. Sci. 2020, 10, 6099. [CrossRef]

149. Yu, M.; Li, Z.; Chen, W.; Rong, T.; Wang, G.; Ma, X. Hermetia illucens larvae as a potential dietary protein source altered the microbiota and modulated mucosal immune status in the colon of finishing pigs. J. Anim. Sci. Biotechnol. 2019, 10, 50. [CrossRef]

150. Wang, S.Y.; Wu, L.; Li, B.; Zhang, D. Reproductive Potential and Nutritional Composition of Hermetia illucens (Diptera: Stratiomyidae) Prepupae Reared on Different Organic Wastes. J. Econ. Entomol. 2020, 113, 527-537. [CrossRef] [PubMed]

151. Cutrignelli, M.I.; Messina, M.; Tulli, F.; Randazzo, B.; Olivotto, I.; Gasco, L.; Loponte, R.; Bovera, F. Evaluation of an insect meal of the Black Soldier Fly (Hermetia illucens) as soybean substitute: Intestinal morphometry, enzymatic and microbial activity in laying hens. Res. Vet. Sci. 2018, 117, 209-215. [CrossRef]

152. Brede, A.; Wecke, C.; Liebert, F. Does the Optimal Dietary Methionine to Cysteine Ratio in Diets for Growing Chickens Respond to High Inclusion Rates of Insect Meal from Hermetia illucens? Animals 2018, 8, 187. [CrossRef] [PubMed]

153. Moniello, G.; Ariano, A.; Panettieri, V.; Tulli, F.; Olivotto, I.; Messina, M.; Randazzo, B.; Severino, L.; Piccolo, G.; Musco, N.; et al. Intestinal Morphometry, Enzymatic and Microbial Activity in Laying Hens Fed Different Levels of a Hermetia illucens Larvae Meal and Toxic Elements Content of the Insect Meal and Diets. Animals 2019, 9, 86. [CrossRef]

154. Kroeckel, S.; Harjes, A.-G.; Roth, I.; Katz, H.; Wuertz, S.; Susenbeth, A.; Schulz, C. When a turbot catches a fly: Evaluation of a pre-pupae meal of the Black Soldier Fly (Hermetia illucens) as fish meal substitute-Growth performance and chitin degradation in juvenile turbot (Psetta maxima). Aquaculture 2012, 364, 345-352. [CrossRef]

155. Schiavone, A.; De Marco, M.; Martínez, S.; Dabbou, S.; Renna, M.; Madrid, J.; Hernandez, F.; Rotolo, L.; Costa, P.; Gai, F. Nutritional value of a partially defatted and a highly defatted black soldier fly larvae (Hermetia illucens L.) meal for broiler chickens: Apparent nutrient digestibility, apparent metabolizable energy and apparent ileal amino acid digestibility. J. Anim. Sci. BioTechnol. 2017, 8, 1-9. [CrossRef]

156. Dumas, A.; Raggi, T.; Barkhouse, J.; Lewis, E.; Weltzien, E. The oil fraction and partially defatted meal of black soldier fly larvae (Hermetia illucens) affect differently growth performance, feed efficiency, nutrient deposition, blood glucose and lipid digestibility of rainbow trout (Oncorhynchus mykiss). Aquaculture 2018, 492, 24-34. [CrossRef]

157. Davys, M.N.G.; Pirie, N.W. A belt press for separating juices from fibrous pulps. J. Agric. Eng. Res. 1965, 10, 142-145. [CrossRef]

158. Chiesa, S.; Gnansounou, E. Protein extraction from biomass in a bioethanol refinery-possible dietary applications: Use as animal feed and potential extension to human consumption. Bioresour. Technol. 2011, 102, 427-436. [CrossRef]

159. Pirie, N.W. Leaf Protein and Its By-Products in Human and Animal Nutrition, 2nd ed.; Cambridge University Press: Cambridge, UK, 1987; p. 299.

160. Stødkilde, L.; Damborg, V.; Jørgensen, H.; Lærke, H.; Jensen, S. Digestibility of fractionated green biomass as protein source for monogastric animals. Animal 2019, 13, 1817-1825. [CrossRef]

161. Baraniak, B. The effect of flocculant applied in the process of fractionating alfalfa juice on the chemical composition of the obtained protein concentrates. Anim. Feed Sci. Technol. 1990, 31, 305-311. [CrossRef]

162. Stødkilde, L.; Damborg, V.K.; Jørgensen, H.; Lærke, H.N.; Jensen, S.K. White clover fractions as protein source for monogastrics: Dry matter digestibility and protein digestibility-corrected amino acid scores. J. Sci. Food Agric. 2018, 98, 2557-2563. [CrossRef] 
163. Kidd, M.T.; Kerr, B.J.; Allard, J.P.; Rao, S.K.; Halley, J.T. Limiting Amino Acid Responses in Commercial Broilers. J. Appl. Poult. Res. 2000, 9, 223-233. [CrossRef]

164. Matti, N. Extraction of leaf protein from green crops. Chemical composition and nutritive value of products of fractionation. Agric. Food Sci. 1983, 55, 143-154. [CrossRef]

165. Santamaría-Fernández, M.; Karkov Ytting, N.; Lübeck, M. Influence of the development stage of perennial forage crops for the recovery yields of extractable proteins using lactic acid fermentation. J. Clean. Prod. 2019, 218, 1055-1064. [CrossRef]

166. Santamaría-Fernández, M.; Molinuevo-Salces, B.; Kiel, P.; Steenfeldt, S.; Uellendahl, H.; Lübeck, M. Lactic acid fermentation for refining proteins from green crops and obtaining a high quality feed product for monogastric animals. J. Clean. Prod. 2017, 162, 875-881. [CrossRef]

167. Szymczyk, B.; Gwiazda, S.; Hanczakowski, P. The effect of leaf protein concentrate from red clover on plasma cholesterol level in rats. J. Sci. Food Agric. 1995, 67, 299-301. [CrossRef]

168. Maciejewicz-Rys, J.; Hanczakowski, P. Improvement of the nutritive value of cereals by leaf protein supplementation. J. Sci. Food Agric. 1990, 50, 99-104. [CrossRef]

169. Grela, E.; Pietrzak, K. Production technology, chemical composition and use of alfalfa protein-xanthophyll concentrate as dietary supplement. J. Food Process. Technol. 2014, 5, 1-5. [CrossRef]

170. Hanczakowski, P.; Szymezyk, B.; Skraba, B. Composition and nutritive value of native and modified green fraction of leaf protein from lucerne (Medicago sativa). J. Sci. Food Agric. 1991, 56, 495-501. [CrossRef]

171. Madhekar, R.D.; Mungikar, A.M. Chemical composition of lucerne (Medicago Sativa L.), it's leaf meal and leaf protein concentrate. J. Phytol. Res. 2009, 22, 95-98.

172. Wiseman, J.; Jagger, S.; Cole, D.; Haresign, W. The digestion and utilization of amino acids of heat-treated fish meal by growing/finishing pigs. Anim. Sci. 1991, 53, 215-225. [CrossRef]

173. Cervantes-Pahm, S.; Stein, H. Ileal digestibility of amino acids in conventional, fermented, and enzyme-treated soybean meal and in soy protein isolate, fish meal, and casein fed to weanling pigs. J. Anim. Sci. 2010, 88, 2674-2683. [CrossRef]

174. Afrose, S.; Hammershøj, M.; Nørgaard, J.V.; Engberg, R.M.; Steenfeldt, S. Influence of blue mussel (Mytilus edulis) and starfish (Asterias rubens) meals on production performance, egg quality and apparent total tract digestibility of nutrients of laying hens. Anim. Feed Sci. Technol. 2016, 213, 108-117. [CrossRef]

175. Jönsson, L.; Wall, H.; Tauson, R. Production and egg quality in layers fed organic diets with mussel meal. Animal 2011, 5, 387-393. [CrossRef]

176. Waldenstedt, L.; Jönsson, L. Mussel Meal as a High Quality Protein Source for Broiler Chickens. In Proceedings of 12th European Poultry Conference at Verona, Italy; World's Poultry Science Association: Beekbergen, The Netherlands, 2006.

177. Wallenbeck, A.; Neil, M.; Lundeheim, N.; Andersson, K. Mussel Meal Diets to Growing/Finishing Pigs: Influence on Performance and Carcass Quality; Book of Abstracts of the 65th Annual Meeting of the European Federation of Animal Science; Wageningen Publishers: Wageningen, The Netherlands, 2014; p. 249.

178. Lacroix, C.; Duvieilbourg, E.; Guillou, N.; Guyomarch, J.; Bassoulet, C.; Moraga, D.; Chapalain, G.; Auffret, M. Seasonal monitoring of blue mussel (Mytilus spp.) populations in a harbor area: A focus on responses to environmental factors and chronic contamination. Mar. Enivron. Res. 2017, 129, 24-35. [CrossRef] [PubMed]

179. European Commission directive 2006/113/EC of the european parliament and of the council of 12 December 2006 on the quality required of shellfish waters. Off. J. Eur. Communities 2006, L376, 14-20.

180. Jönsson, L.; Holm, L. Effects of toxic and non-toxic blue mussel meal on health and product quality of laying hens. J. Anim. Physiol. Anim. Nutr. 2010, 94, 405-412. [CrossRef] [PubMed]

181. Selle, P.H.; Cowieson, A.J.; Ravindran, V. Consequences of calcium interactions with phytate and phytase for poultry and pigs. Livestock Sci. 2009, 124, 126-141. [CrossRef]

182. Qian, H.; Kornegay, E.; Conner, D., Jr. Adverse effects of wide calcium: Phosphorus ratios on supplemental phytase efficacy for weanling pigs fed two dietary phosphorus levels. J. Anim. Sci. 1996, 74, 1288-1297. [CrossRef] [PubMed]

183. Poulsen, H.D. Phosphorus utilization and excretion in pig production. J. Environ. Qual. 2000, 29, 24-27. [CrossRef]

184. Ruan, Z.; Zhang, Y.-G.; Yin, Y.-L.; Li, T.-J.; Huang, R.-L.; Kim, S.; Wu, G.; Deng, Z. Dietary requirement of true digestible phosphorus and total calcium for growing pigs. Asian-Australas. J. Anim. Sci. 2007, 20, 1236-1242. [CrossRef]

185. De Vries, S.; Kwakkel, R.; Dijkstra, J. Dynamics of calcium and phosphorus metabolism in laying hens. In Phosphorus and Calcium Utilization and Requirements in Farm Animals; Vitti, D.M.S.S., Kebreab, E., Eds.; CABI: Wallingford, UK, 2010 ; pp. $133-150$.

186. Biasato, I.; Renna, M.; Gai, F.; Dabbou, S.; Meneguz, M.; Perona, G.; Martinez, S.; Lajusticia, A.C.B.; Bergagna, S.; Sardi, L. Partially defatted black soldier fly larva meal inclusion in piglet diets: Effects on the growth performance, nutrient digestibility, blood profile, gut morphology and histological features. J. Anim. Sci. BioTechnol. 2019, 10, 1-11. [CrossRef]

187. Spranghers, T.; Michiels, J.; Vrancx, J.; Ovyn, A.; Eeckhout, M.; De Clercq, P.; De Smet, S. Gut antimicrobial effects and nutritional value of black soldier fly (Hermetia illucens L.) prepupae for weaned piglets. Anim. Feed Sci. Technol. 2018, 235, 33-42. [CrossRef]

188. Bovera, F.; Loponte, R.; Pero, M.E.; Cutrignelli, M.I.; Calabrò, S.; Musco, N.; Vassalotti, G.; Panettieri, V.; Lombardi, P.; Piccolo, G. Laying performance, blood profiles, nutrient digestibility and inner organs traits of hens fed an insect meal from Hermetia illucens larvae. Res. Vet. Sci. 2018, 120, 86-93. [CrossRef]

189. Nery, J.; Gasco, L.; Dabbou, S.; Schiavone, A. Protein composition and digestibility of black soldier fly larvae in broiler chickens revisited according to the recent nitrogen-protein conversion ratio. J. Insects Food Feed 2018, 4, 171-177. [CrossRef] 
190. Meyer, S.; Gessner, D.K.; Braune, M.S.; Friedhoff, T.; Most, E.; Höring, M.; Liebisch, G.; Zorn, H.; Eder, K.; Ringseis, R. Comprehensive evaluation of the metabolic effects of insect meal from Tenebrio molitor L. in growing pigs by transcriptomics, metabolomics and lipidomics. J. Anim. Sci. BioTechnol. 2020, 11, 1-19. [CrossRef]

191. Yu, M.; Li, Z.; Chen, W.; Rong, T.; Wang, G.; Li, J.; Ma, X. Use of Hermetia illucens larvae as a dietary protein source: Effects on growth performance, carcass traits, and meat quality in finishing pigs. Meat Sci. 2019, 158, 107837. [CrossRef] [PubMed]

192. Yu, M.; Li, Z.; Chen, W.; Rong, T.; Wang, G.; Wang, F.; Ma, X. Evaluation of full-fat Hermetia illucens larvae meal as a fishmeal replacement for weanling piglets: Effects on the growth performance, apparent nutrient digestibility, blood parameters and gut morphology. Anim. Feed Sci. Technol. 2020, 264, 114431. [CrossRef]

193. Biasato, I.; De Marco, M.; Rotolo, L.; Renna, M.; Lussiana, C.; Dabbou, S.; Capucchio, M.T.; Biasibetti, E.; Costa, P.; Gai, F.; et al. Effects of dietary Tenebrio molitor meal inclusion in free-range chickens. J. Anim. Physiol. Anim. Nutr. 2016, 100, 1104-1112. [CrossRef] [PubMed]

194. Khan, S.; Khan, R.; Alam, W.; Sultan, A. Evaluating the nutritive profile of three insect meals and their effects to replace soya bean in broiler diet. J. Anim. Physiol. Anim. Nutr. 2018, 102, 662-668. [CrossRef] [PubMed]

195. Bovera, F.; Piccolo, G.; Gasco, L.; Marono, S.; Loponte, R.; Vassalotti, G.; Mastellone, V.; Lombardi, P.; Attia, Y.A.; Nizza, A. Yellow mealworm larvae (Tenebrio molitor, L.) as a possible alternative to soybean meal in broiler diets. Br. Poult. Sci. 2015, 56, 569-575. [CrossRef] [PubMed]

196. Dabbou, S.; Gai, F.; Biasato, I.; Capucchio, M.T.; Biasibetti, E.; Dezzutto, D.; Meneguz, M.; Plachà, I.; Gasco, L.; Schiavone, A. Black soldier fly defatted meal as a dietary protein source for broiler chickens: Effects on growth performance, blood traits, gut morphology and histological features. J. Anim. Sci. BioTechnol. 2018, 9, 1-10. [CrossRef]

197. Leiber, F.; Gelencsér, T.; Stamer, A.; Amsler, Z.; Wohlfahrt, J.; Früh, B.; Maurer, V. Insect and legume-based protein sources to replace soybean cake in an organic broiler diet: Effects on growth performance and physical meat quality. Renew. Agric. Food Syst. 2017, 32, 21-27. [CrossRef]

198. Marono, S.; Loponte, R.; Lombardi, P.; Vassalotti, G.; Pero, M.; Russo, F.; Gasco, L.; Parisi, G.; Piccolo, G.; Nizza, S. Productive performance and blood profiles of laying hens fed Hermetia illucens larvae meal as total replacement of soybean meal from 24 to 45 weeks of age. Poult. Sci. 2017, 96, 1783-1790. [CrossRef] [PubMed]

199. Joint FAO/WHO Expert Consultation Protein quality evaluation. In Report of Joint FAO/WHO Expert Consultation; FAO/WHO: Rome, Italy, 1991; pp. 1-66.

200. Szymczyk, B.; Gwiazda, S.; Hanczakowski, P. The nutritive value for rats and chicks of unextracted and defatted leaf protein concentrates from red clover and Italian ryegrass. Anim. Feed Sci. Technol. 1996, 63, 297-303. [CrossRef]

201. Hegsted, M.; Linkswiler, H.M. Protein quality of high and low saponin alfalfa protein concentrate. J. Sci. Food Agric. 1980, 31, 777-781. [CrossRef] [PubMed]

202. Terry, R.A.; Tilley, J.M.A. The digestibility of the leaves and stems of perennial ryegrass, cocksfoot, timothy, tall fescue, lucerne and sainfoin, as measured by an in vitro procedure. Grass Forage Sci. 1964, 19, 363-372. [CrossRef]

203. Rinne, M.; Jaakkola, S.; Huhtanen, P. Grass maturity effects on cattle fed silage-based diets. 1. Organic matter digestion, rumen fermentation and nitrogen utilization. Anim. Feed Sci. Technol. 1997, 67, 1-17. [CrossRef]

204. Cowlishaw, S.J.; Eyles, D.E.; Raymond, W.F.; Tilley, J.M.A. Nutritive value of leaf protein concentrates. II. J. Sci. Food Agric. 1956, 7,775-780. [CrossRef]

205. Cheeke, P.R.; Kinzell, J.H.; De Fremery, D.; Kohler, G.O. Freeze-Dried and Commercially-Prepared Alfalfa Protein Concentrate Evaluation with Rats and Swine. J. Anim. Sci. 1977, 44, 772-777. [CrossRef]

206. Szymczyk, B.; Gwiazda, S.; Hanczakowski, P. Nutritive value for rats of unextracted and defatted green fractions of leaf protein concentrate from red clover. Anim. Feed Sci. Technol. 1995, 56, 169-175. [CrossRef]

207. Hanczakowski, P.; Skraba, B. The effect of different precipitating agents on quality of leaf protein concentrate from lucerne. Anim. Feed Sci. Technol. 1984, 12, 11-17. [CrossRef]

208. Lærke, H.N.; Stødkilde, L.; Ambye-Jensen, M.; Jensen, S.K.; Sørensen, J.F.; Nørgaard, J.V.; Knudsen, K.E.B. Extracts of Green Biomass as Source of Protein for Pigs; Crovetto, G.M., Ed.; EAAP: Parma, Italy, 2019; pp. 177-178.

209. Donnelly, P.E.; McDonald, R.M. Leaf protein concentrate quality: The effect pf pasture species and reducing agent. Proc. Nutr. Soc. N. Zeal. 1979, 3, 84-95.

210. Subba Rau, B.H.; Ramana, K.V.R.; Singh, N. Studies on nutritive value of leaf proteins and some factors affecting their quality. J. Sci. Food Agric. 1972, 23, 233-245. [CrossRef] [PubMed]

211. Henry, K.M.; Ford, J.E. The nutritive value of leaf protein concentrates determined in biological tests with rats and by microbiological methods. J. Sci. Food Agric. 1965, 16, 425-432. [CrossRef]

212. Houseman, R.A. The utilization of the products of green-crop fractionation by pigs and ruminants. Proc. Nutr. Soc. 1976, 35, 213-220. [CrossRef]

213. Ameenuddin, S.; Bird, H.R.; Pringle, D.J.; Sunde, M.L. Studies on the Utilization of Leaf Protein Concentrates as a Protein Source in Poultry Nutrition1. Poult. Sci. 1983, 62, 505-511. [CrossRef] [PubMed]

214. Myer, R.O.; Cheeke, P.R.; Kennick, W.H. Utilization of Alfalfa Protein Concentrate by Swine. J. Anim. Sci. 1975, 40, 885-891. [CrossRef]

215. Pietrzak, E.; Grela, E.R. The effects of adding lucerne protein concentrate to diets on the reproductive traits and blood metabolic profiles of sows and piglets. J. Anim. Feed Sci. 2015, 24, 216-225. [CrossRef] 
216. Hsu, A.; Allee, G.L. Feeding value of Alfalfa Leaf Protein Concentrate (ALPC) for swine. In Conference: Swine Day; Kansas State University, Agricultural Experiment Station and Cooperative Extension Service: Manhattan, KS, USA, 1980; pp. 1-5.

217. Sugimoto, N.; Miyazaki, H.; Saito, T. Studies on the utilization of green-leaf protein concentrate in swine 2. The Effect of Green-leaf Protein Concentrate on the Performance and Carcass Quality of Growing-finishing Pigs. Jpn. J. Swine Husb. Res. 1986, $23,157-164$. [CrossRef]

218. Barber, R.S.; Braude, R.; Mitchell, K.G.; Partridge, I.G. Lucerne juice as a protein supplement for growing pigs: Effects of mineral content of the diet and of the water supply. Anim. Feed Sci. Technol. 1981, 6, 35-41. [CrossRef]

219. Barber, R.S.; Braude, R.; Mitchell, K.G.; Partridge, I.G.; Pittman, R.J. Value of freshly produced lucerne juice as a source of supplemental protein for the growing pig. Anim. Feed Sci. Technol. 1980, 5, 215-220. [CrossRef]

220. Barber, R.S.; Braude, R.; Mitchell, K.G.; Partridge, I.G.; Pittman, R.J. Value of lucerne juice and grass juice as sources of protein for the growing pig. Anim. Feed Sci. Technol. 1979, 4, 233-262. [CrossRef]

221. Carton, O.; Maguire, M.F.; Craig, J. The Nutritive-Value of Preserved Grass Juice for Growing-Pigs. Irish J. Agric. Res. 1983, 22, 95-104.

222. Lima, I.; Richardson, T.; Stahmann, M. Leaf proteins as foodstuffs, Fatty acids in some leaf protein concentrates. J. Agric. Food Chem. 1965, 13, 143-145. [CrossRef]

223. Carr, J.R.; Pearson, G. Photosensitisation, growth performance, and carcass measurements of pigs fed diets containing commercially prepared lucerne leaf-protein concentrate. N. Zeal. J. Exp. Agric. 1976, 4, 45-50. [CrossRef]

224. Kwiatkowska, K.; Kwiecien, M.; Winiarska-Mieczan, A. Fast-growing chickens fed with lucerne protein-xanthophyll concentrate: Growth performance, slaughter yield and bone quality. J. Anim. Feed Sci. 2017, 26, 131-140. [CrossRef]

225. Cowlishaw, S.J.; Eyles, D.E.; Raymond, W.F.; Tilley, J.M.A. Nutritive value of leaf protein concentrates. I. Effect of addition of cholesterol and amino-acids. J. Sci. Food Agric. 1956, 7, 768-774. [CrossRef]

226. Myer, R.O.; Cheeke, P.R. Utilization of Alfalfa Meal and Alfalfa Protein Concentrate by Rats. J. Anim. Sci. 1975, 40, 500-508. [CrossRef]

227. Horigome, T.; Kim, J.K.; Uchida, S. Nutritive Quality of Leaf Proteins Coagulated at Different pH. J. Nutr. Sci. Vitaminol. 1983, 29, 611-620. [CrossRef]

228. Hove, E.L.; Lohrey, E.; Urs, M.K.; Allison, R.M. The effect of lucerne-protein concentrate in the diet on growth, reproduction and body composition of rats. Br. J. Nutr. 1974, 31, 147-157. [CrossRef] [PubMed] 